\title{
Serotonin Induces Tonic Firing in Layer V Pyramidal Neurons of Rat Prefrontal Cortex during Postnatal Development
}

\author{
Zhong-wei Zhang \\ Centre de Recherche Université Laval Robert-Giffard, Département de Psychiatrie, Faculté de Médicine, Université Laval, Québec City, G1J 2G3, Canada
}

The effects of serotonin (5-HT) on neuronal activity were examined during postnatal development in layer $\mathrm{V}$ pyramidal neurons of the rat prefrontal cortex (PFC) in vitro. Whole-cell patch-clamp recordings were made in slices obtained from rats aged between postnatal day (P) 6 and P31. In P14 or younger neurons, bath application of 5-HT (10 $\mu \mathrm{M})$ induced a large depolarization followed by tonic firing at 2-5 Hz. The excitatory effects of 5-HT decreased rapidly after P14, so that by P21, 5-HT produced a small depolarization or hyperpolarization without cell firing. The excitatory effects of 5-HT at younger ages were attributed to $5-\mathrm{HT}_{2 \mathrm{~A}}$ receptors because the effects were mimicked by the $5-\mathrm{HT}_{2}$ agonist $\alpha$-methyl-5-HT but not by the $5-\mathrm{HT}_{3}$ agonist 1-(m-chlorophenyl)-biguanide, nor by the $5-\mathrm{HT}_{2 \mathrm{~B} / 2 \mathrm{C}}$ agonist 1-(3chlorophenyl)piperazine, and were blocked by the $5-\mathrm{HT}_{2 \mathrm{~A}}$ antagonists ketanserin and $\alpha$-phenyl-1-(2-phenylethyl)-4-piperidinemethanol. The excitatory responses persisted in $0\left[\mathrm{Ca}^{2+}\right]_{0}$ and high $\left[\mathrm{Mg}^{2+}\right]_{0}$ in the presence of TTX or blockers of ionotropic glutamate receptors, suggesting that the effects were mediated essentially by postsynaptic mechanisms. The responses to 5-HT involve a reduction of $\mathrm{K}^{+}$conductance and an enhancement of the hyperpolarization-activated $\mathrm{Na}^{+} / \mathrm{K}^{+}$current. The developmental decline of 5-HTinduced excitatory effects was associated with a downregulation of $5-\mathrm{HT}_{2 \mathrm{~A}}$ receptor function and a decrease in the input resistance during early life. These results suggest that 5-HT is an important regulator of neuronal activity in the neonatal PFC and may play a role in activity-dependent developmental processes.

Key words: neocortex; slice; patch clamp; serotonin; excitation; development; postnatal

\section{Introduction}

The prefrontal cortex (PFC) in mammals is defined as the cortical areas that receive specific innervation from the mediodorsal nucleus of the thalamus (Uylings and van Eden, 1990; Ongur and Price, 2000). The PFC makes up a large portion of the frontal lobe and undergoes progressive expansion in higher mammals, reaching its greatest development in humans (Le Gros Clark, 1932; Rakic and Goldman-Rakic, 1982). In rats, the prelimbic, infralimbic, and dorsal anterior cingulate areas are the major subdivisions of the PFC (Krettek and Price, 1977; Groenewegen, 1988).

Functional studies suggest that the PFC, via its integration into the neural network of the basal ganglia, plays a key role in major cognitive functions (Goldman-Rakic, 1987, 1995; Fuster, 1991), and damages to the PFC produce deficits including memory maintenance and future planning (Kolb, 1984; Fuster, 1985). PFC malfunction has been implicated in several mental illnesses, in particular schizophrenia. Deficiency in the working-memory processes in the PFC has been associated with the symptoms and cognitive deficits that are prominent of schizophrenia (Goldman-Rakic, 1994; Weinberger and Berman, 1996). Although the causes for such malfunction may be complex, many

\footnotetext{
Received Sept. 6, 2002; revised Jan. 24, 2003; accepted Jan. 29, 2003.

This work was supported by the National Alliance for Research on Schizophrenia and Depression and Fond de Recherche en Santé du Québec. Z.W.Z. is a New Investigator of the Canadian Institutes of Health Research. I am grateful to André Parent and Martin Deschênes for sharing equipment, M. Deschênes for discussion, and K. Krnjevic for reading a previous version of this manuscript.

Correspondence should be addressed to Dr. Zhong-wei Zhang, Centre de Recherche U-Laval Robert-Giffard, 2601, de la Canardière, F-6500, Québec, PQ, G1J 2G3, Canada. E-mail: zhongwei.zhang@crulrg.ulaval.ca. Copyright $\odot 2003$ Society for Neuroscience $\quad 0270-6474 / 03 / 233373-12 \$ 15.00 / 0$
}

studies suggest developmental abnormalities implicating both genetic and environmental factors (Jones, 1997; Raedler et al., 1998; Lewis and Levitt, 2002).

The first few weeks after birth are a critical period for the development of the PFC. In rats, the immature PFC at birth contains primarily undifferentiated neurons, tightly packed in the cortical plate. Differentiation of neurons and formation of cortical layers occur over the next 2 weeks in an inside-out order and achieve an adult-like pattern by day 18 (Van Eden and Uylings, 1985).

Serotonin (5-HT) has been extensively implicated in development, affecting functions as diverse as cell proliferation, differentiation, and apoptosis (Lauder, 1990; Azmitia, 2001). Midbrain 5-HT neurons are among the first neurons in the brain to undergo differentiation (Lauder and Bloom, 1974; Lidov and Molliver, 1982). In rats, 5-HT innervation is already present before birth in many areas, including the primordial cortical plate (Dori et al., 1996). Recent studies emphasize a key role for 5-HT in the postnatal development of the brain. Depletion or excess of brain 5-HT in early life delays or disrupts the formation of barrel-like structures in layer IV of the rodent somatosensory cortex (Bennett-Clarke et al., 1994; Cases et al., 1996). Depletion of 5 -HT in newborn rats permanently reduces synapses in the hippocampus (Yan et al., 1997). The developmental effects of 5-HT are mediated by several receptor subtypes, including $5-\mathrm{HT}_{1 \mathrm{~A}}$ and 5- $\mathrm{HT}_{1 \mathrm{~B}}$ (Salichon et al., 2001; Gross et al., 2002), and involve activity-dependant mechanisms (Rhoades et al., 1994; Laurent et al., 2002).

In the PFC, several types of 5-HT receptors, including 5- $\mathrm{HT}_{1 \mathrm{~A}}$ 
and $5-\mathrm{HT}_{2 \mathrm{~A}}$, are expressed during early life (Zilles et al., 1985; Roth et al., 1991). However, little is known about the role of 5-HT in the postnatal development of the PFC. This study examined the effects of 5-HT on neuronal activity in the PFC during early life using patch-clamp recording in slices.

\section{Materials and Methods}

Slice preparations. Brain slices were prepared from Sprague Dawley rats of either sex and aged postnatal day (P) 6-P31 (with the day of birth as P0). All procedures were performed according to the guidelines of the Canadian Council on Animal Care and approved by the Animal Care Committee at Laval University. Briefly, rats were deeply anesthetized with ketamine and xylazine and then decapitated. The brain was removed quickly $(<60 \mathrm{sec}$ ) and placed in ice-cold artificial CSF (ACSF) containing (in mM): $124 \mathrm{NaCl}, 3 \mathrm{KCl}, 2 \mathrm{CaCl}_{2}, 1.3 \mathrm{MgSO}_{4}, 1 \mathrm{NaH}_{2} \mathrm{PO}_{4}, 26 \mathrm{NaHCO}_{3}$, 10 glucose, saturated with $95 \% \mathrm{O}_{2}$ and $5 \% \mathrm{CO}_{2}$. Coronal slices including the prelimbic area were cut at $300-400 \mu \mathrm{m}$ on a vibrating tissue slicer (Vibratome 1000, Pelco, Redding, CA; or VT 1000s, Leica, Nussloch, Germany) and kept in ACSF gassed with $95 \% \mathrm{O}_{2}$ and $5 \% \mathrm{CO}_{2}$ at room temperature. Slices were allowed to recover for at least $1 \mathrm{hr}$ before any recording.

A slice was transferred to a submerge-type chamber in which it was continuously exposed to ACSF, saturated with $95 \% \mathrm{O}_{2}$ and $5 \% \mathrm{CO}_{2}$, and flowing at a rate of $2 \pm 0.2 \mathrm{ml} / \mathrm{min}$ as monitored with a flowmeter (GF-2100; Gilmont Instruments, Barrington, IL). The slice was viewed first with a $4 \times$ objective, and the prelimbic area of the PFC was localized as the area between the forceps minor corpus callosum and the midline (Paxinos and Watson, 1998). Layers I, II-III, V, and VI of the prelimbic area were then viewed under near-infrared illumination with a $40 \times$ water-immersion objective (Fluor, $40 \times / 0.80 \mathrm{~W}$; Nikon, Tokyo, Japan) and a CCD camera (CCD-300-RC; Dage-MTI, Michigan City, IN). Layer $\mathrm{V}$ pyramidal neurons were identified by their large size and apical dendrite. I randomly checked the morphology of recorded cells in 25 slices with biocytin labeling (Zhang and Deschenes, 1997; Reyes and Sakmann, 1999). All 25 cells were pyramidal neurons with apical dendrites extending into layer I.

Patch-clamp recording. Electrodes were pulled from thick-wall borosilicate glass (1.5/0.84 mm; World Precision Instruments, Sarasota, FL) on a horizontal puller (P-97; Sutter Instruments, Novato, CA). The pipette solution contained (in $\mathrm{mM}$ ): $120 \mathrm{~K}$-gluconate, $10 \mathrm{KCl}, 0.5 \mathrm{EGTA}, 2$ $\mathrm{MgCl}_{2}, 4$ ATP-Na $2,0.3$ GTP-Na, 10 HEPES, pH 7.4, with KOH, 280 mOsm. Electrodes had resistances between 3 and $7 \mathrm{M} \Omega$. The seal resistance was $>5 \mathrm{G} \Omega$. Whole-cell recordings were made from the soma with an Axopatch 200B amplifier (Axon Instruments, Foster City, CA). Current-clamp recording was performed in fast current-clamp mode with $95 \%$ serial resistance $\left(R_{\mathrm{s}}\right)$ compensation. For voltage-clamp recording, $R_{\mathrm{s}}$ was between 10 and $25 \mathrm{M} \Omega$ and compensated $85 \%$ at $100 \mu$ sec lag. $R_{\mathrm{s}}$ was monitored either throughout the recording or at the beginning and end. Data were excluded if there was a $>30 \%$ change in $R_{\mathrm{s}}$ during the recording. Experiments were conducted using the Clampex program (pClamp 6, Axon Instruments), and data were stored either in a computer or on tape (VR-10B; InstruTech, Port Washington, NY).

Drugs and drug delivery. All agents were applied by changing the bath perfusate from standard ACSF to modified ACSF, to which various drugs were simply added. All solutions were continuously bubbled with $95 \%$ $\mathrm{O}_{2}$ and $5 \% \mathrm{CO}_{2}$. With a perfusion flow of $2 \mathrm{ml} / \mathrm{min}$, complete solution exchange at the site of recording required $\sim 2$ min after switching the perfusates. To minimize degradation, 5-HT was added to ACSF containing $100 \mu \mathrm{M}$ sodium metabisulfate, and both overhead and microscope lights were turned off during the recording. Application of $100 \mu \mathrm{M}$ sodium metabisulfate by itself did not induce any change in membrane potential. All experiments were conducted at room temperature $\left(23-25^{\circ} \mathrm{C}\right)$.

5-HT, $\alpha$-methyl-5-HT, 1-(m-chlorophenyl)-biguanide (mCPBG), and (-)-bicuculline methodide were obtained from Sigma/RBI (Natick, MA). Ketanserin, $\alpha$-phenyl-1-(2-phenylethyl)-4-piperidinemethanol (MDL 11939), 1-(3-chlorophenyl)piperazine (m-CPP), D-(-)-2-amino-5-phosphonopentanoic acid (D-AP5), 6,7-dinitroquinoxaline-2,3-dione (DNQX), 4- ethylphenylamino-1,2-dimethyl-6-methylaminopyrimidinium chloride (ZD 7288), 1-(2-methoxyphenyl)-4-(4-phthalimidobutyl)piperazine hydrobromide (NAN-190), and ( \pm )-8-hydroxy-2-dipropylaminotetralin hydrobromide (8$\mathrm{OH}-\mathrm{DPAT}$ ) were obtained from Tocris Cookson (Ballwin, MO). All other chemicals were purchased from Sigma-Aldrich (Oakville, ON).

Data analysis. The Clampfit 6, AxoGraph 4 (Axon Instruments), KaleidaGraph (Synergy Software, Reading, PA), and Origin 7 (OriginLab, Nothampton, MA) were used for analysis. Unless indicated otherwise, data were filtered at $1 \mathrm{kHz}$ and digitized at $4 \mathrm{kHz}$. Input resistance was measured in either current- or voltage-clamp mode by applying hyperpolarizing current or voltage steps. Spike threshold was measured for the first action potential evoked by a depolarizing current pulse. The amplitude of 5-HT-induced responses (voltage or current) was measured by averaging a segment of $5 \mathrm{sec}$ around the peak. The liquid junction potential was estimated to be $14 \mathrm{mV}$ (Axoscope 1.0, Axon Instruments), and corrections were made accordingly to all membrane potentials.

Means are given \pm SEM throughout. Means were compared by twotailed Student's $t$ test; the incidence of cell firing was compared by Fisher's exact test.

\section{Results}

Data were collected from 262 neurons obtained from 67 rats. This study focused on layer $V$ pyramidal neurons because they provide the principal output of the cortex and project extensively to the dorsal and ventral striatum (Jones et al., 1977; Selemon and Goldman-Rakic, 1985; Sesack et al., 1989; Berendse et al., 1992; Levesque and Parent, 1998).

\section{5-HT induces tonic firing in pyramidal neurons during early life}

At $\mathrm{P}$ 9, layer $\mathrm{V}$ pyramidal neurons recorded in current-clamp mode showed a resting membrane potential of $-69 \pm 1 \mathrm{mV}(n=$ $24)$ and fired a train of action potential with moderate accommodation in response to a depolarizing current pulse (Fig. 1A,B). Bath perfusion of $10 \mu \mathrm{M} 5$-HT induced a membrane depolarization that reached the threshold within $30 \mathrm{sec}$, after which the cell fired regularly at $2-5 \mathrm{~Hz}$ (Fig. 1C). The effects of 5-HT on membrane potential were reversible, and the cell recovered completely after 10-15 min wash (Fig. 1C). Similar responses were observed in 17 of 18 neurons recorded at $\mathrm{P} 9$.

To determine whether multiple responses can be obtained from a single cell, I made a second application of 5-HT (10 $\mu \mathrm{M})$ in three cells after recovery from the first application. All three cells showed a second response that was qualitatively similar to the first one (data not shown).

\section{Decline of 5-HT-induced excitation during postnatal development}

To determine whether this excitatory effect of 5-HT is developmentally related, I recorded from layer $\mathrm{V}$ pyramidal neurons obtained from rats aged $\mathrm{P} 6-\mathrm{P} 31$. As in other parts of the neocortex, cortical layers of the prelimbic area form during the first 2 weeks after birth. At P6, layer V is still underdeveloped but can be identified as a broad band between undifferentiated layer II-III and more advanced layer VI (Van Eden and Uylings, 1985). Application of 5-HT $(10 \mu \mathrm{M})$ reversibly induced tonic firing in 10 of 16 cells (62\%) recorded at P6 (excited cells) (Fig. 2). The proportion of cells showing tonic firing increased to $97 \%$ at P9/10 (29 of 30 cells; $p<0.005$ vs P6; two-tailed Fisher's exact test) (Fig. 2) and then decreased slightly but remained high until P14 (75\%; 18 of $24 ; p<0.04$ vs P9/10). The excitatory effects of 5-HT decreased dramatically after P14. The percentage of cells that showed tonic firing in response to 5-HT (10 $\mu \mathrm{M})$ dropped to $35 \%$ by P16 (16 of $46 ; p<0.003$ vs $\mathrm{P} 14)$, to $9 \%$ by $\mathrm{P} 18$ ( 1 of $11 ; p<0.001$ vs $\mathrm{P} 14$ ), 
A

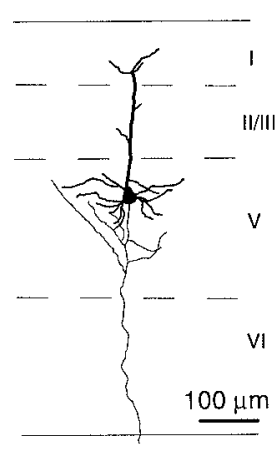

B

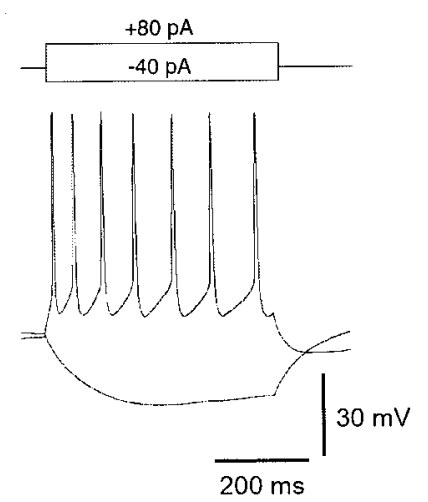

C

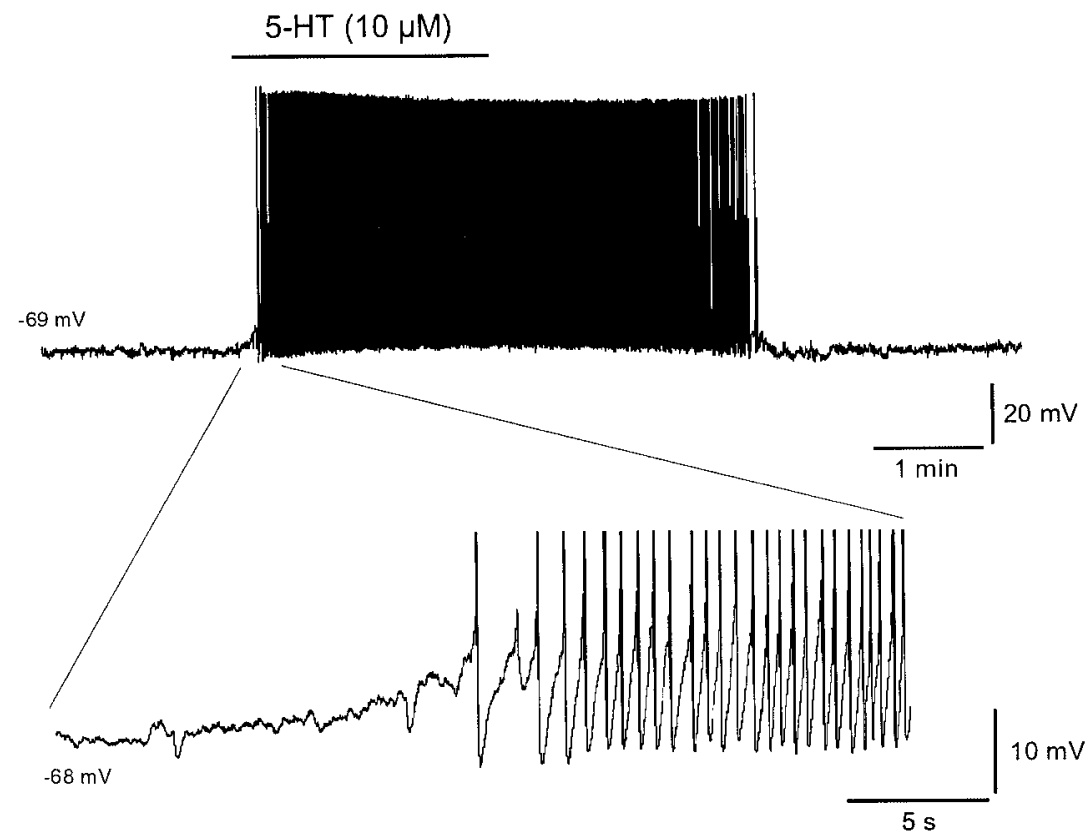

Figure 1. Action of 5-HT on membrane potential of a layer V pyramidal neuron at P9. A, Camera lucida reconstruction of a layer $V$ pyramidal neuron in the prelimbic cortex at $P 9$. The cell was labeled with $0.25 \%$ biocytin in the recording pipette. The apical dendrite extends into layer $I$, and the axon can be followed until the white matter. $B$, Membrane potential changes in response to depolarizing and hyperpolarizing current pulses ( 80 and $-40 \mathrm{pA}$, respectively; top traces) recorded at the soma in current clamp. The resting potential was $-69 \mathrm{mV}$, input resistance was $665 \mathrm{M} \Omega$, and time constant was $80 \mathrm{msec}$. C, Bath application of 5-HT (10 $\mu \mathrm{M}, 2.5 \mathrm{~min}$ ) induced a slow depolarization followed by a period of tonic firing at $\sim 3 \mathrm{~Hz}$. The period of 5-HT application is indicated by the horizontal bar. The bottom trace shows the initial responses at a faster scale, and action potentials are truncated for clarity. In this and the following figures, the resting potential is indicated at the beginning of the trace.

and finally to $0 \%$ by P21 ( 0 of 16$)$ and remained at $0 \%$ by P30/31 (0 of 22).

The effects of 5-HT in neurons recorded at older ages were also more diverse. All cells aged P14 or younger showed a large depolarization $(>10 \mathrm{mV})$ in response to 5-HT application. In contrast, cells aged P21 showed either a small depolarization $(2.8 \pm 0.3 \mathrm{mV} ; n=8)$ (Fig. $2 A)$ or a moderate hyperpolarization $(-1.8 \pm 0.3 \mathrm{mV} ; n=6)$ in response to 5 -HT $(10 \mu \mathrm{M})$. Similar responses were observed at P30/31 with amplitudes of $3.6 \pm 0.5 \mathrm{mV}(n=7)$ and $-3.2 \pm 0.9 \mathrm{mV}(n=6)$ for depolarizing and hyperpolarizing responses, respectively. Higher concentrations of 5-HT ( 50 or $100 \mu \mathrm{M}$ ) produced similar responses to those obtained with $10 \mu \mathrm{M} 5$-HT, and none of the cells fired action potential in response to 5-HT application $(n=5 ; \mathrm{P} 20-\mathrm{P} 29)$. The 5-HT-induced hyperpolarization was reversibly blocked by the selective $5-\mathrm{HT}_{1 \mathrm{~A}}$ antagonist NAN$190(0.5 \mu \mathrm{M} ; n=3)$ and mimicked by the selective $5-\mathrm{HT}_{1 \mathrm{~A}}$ agonist 8 -OH-DPAT $(10 \mu \mathrm{M} ;-2.3 \pm$ $0.4 \mathrm{mV} ; n=3)$, suggesting an upregulation of $5-\mathrm{HT}_{1 \mathrm{~A}}$ receptor function during early life. These observations were consistent with results obtained previously from adult or young adult PFC neurons (Araneda and Andrade, 1991; Tanaka and North, 1993).

\section{$5-\mathrm{HT}_{2 \mathrm{~A}}$ signaling mediates \\ 5-HT-induced excitation}

$5-\mathrm{HT}_{2 \mathrm{~A} / 2 \mathrm{C}}$ and $5-\mathrm{HT}_{3}$ receptor subtypes have been shown to mediate excitatory responses in the brain of immature and adult rats (Andrade and Nicoll, 1987; Sugita et al., 1992; Tanaka and North, 1993; Roerig et al., 1997; Eriksson et al., 2001; Foehring et al., 2002). To determine the role of these receptor subtypes, I examined the effects of selective agonists and antagonists in layer $\mathrm{V}$ pyramidal neurons aged between P9 and P14 when 5-HT consistently produced strong excitatory effects (Fig. 2).

As illustrated in Figure $3 A$, the selective agonist of $5-\mathrm{HT}_{3}$ receptor, mCPBG (50 $\mu \mathrm{M})$, had no effect on membrane potential $(-0.1 \pm 0.1 \mathrm{mV} ; n=6 ; p>0.6$; Student's $t$ test). In contrast, $\alpha$-methyl-5-HT $(20 \mu \mathrm{M})$, which activates all $5-\mathrm{HT}_{2}$ receptors, mimicked the responses by $5-\mathrm{HT}$, evoking a slow depolarization followed by a period of tonic firing in all cells recorded $(n=6)$. Finally, m-CPP $(20 \mu \mathrm{M})$, the selective agonist of $5-\mathrm{HT}_{2 \mathrm{~B} / 2 \mathrm{C}}$ (Conn and Sanders-Bush, 1987), had no significant effects $(0.1 \pm 0.4 \mathrm{mV} ; n=6 ; p>0.7)$ (Fig. $3 B)$. These results suggest that the excitatory effects of 5-HT are mediated by $5-\mathrm{HT}_{2 \mathrm{~A}}$ receptors.

Specific antagonists were used to confirm the role of $5-\mathrm{HT}_{2 \mathrm{~A}}$ receptors. 5- $\mathrm{HT}$ induced excitatory responses were essentially blocked by ketanserin $(2 \mu \mathrm{M} ; n=4)$ (Fig. $4 \mathrm{~A}$ ), the $5-\mathrm{HT}_{2}$ antagonist that is relatively selective for $5-\mathrm{HT}_{2 \mathrm{~A}}$. The effects of ketanserin were not reversible after $30 \mathrm{~min}$ wash. However, it should be noted that even at this high concentration of ketanserin, a small depolarization persisted $(1.7 \pm 0.2 \mathrm{mV} ; n=4 ; p<$ $0.01)$. Similar results were obtained with MDL 11939 (0.4 $\mu \mathrm{M}$; $n=4$ ) (Fig. $4 \mathrm{~B}$ ), another selective antagonist of $5-\mathrm{HT}_{2 \mathrm{~A}}$ receptors (Aloyo and Harvey, 2000). These results suggest that $5-\mathrm{HT}_{2 \mathrm{~A}}$ is the predominant receptor subtype involved in 5-HT-induced excitatory effects.

To determine whether $5-\mathrm{HT}_{2}$ receptors are responsible for 5-HT-induced depolarization in older rats, the effect of ketanserin on 5-HT-induced responses was examined in neurons at P22-P23. As illustrated in Figure $4 C$, ketanserin $(0.5 \mu \mathrm{M})$ reduced 5 -HT-induced depolarization by $\sim 50 \%$ in a neuron at P22. Similar results were obtained in all five cells tested, with an average reduction of $66 \pm 6 \%(n=5$ cells; $p<0.02)$. This result suggests that $5-\mathrm{HT}_{2}$ receptors contribute significantly to 5-HT-induced excitatory effects in the PFC of young 
A
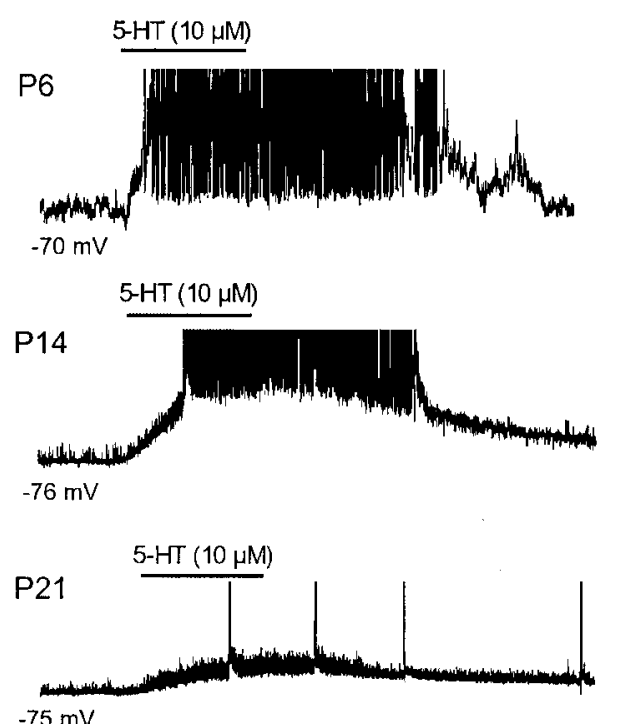

$-75 \mathrm{mV}$

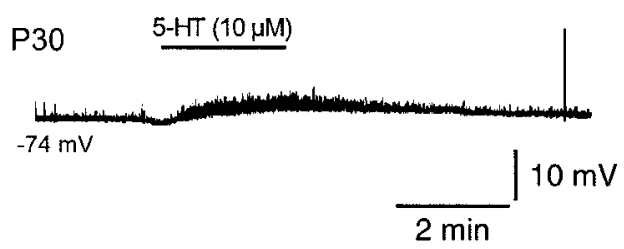

B

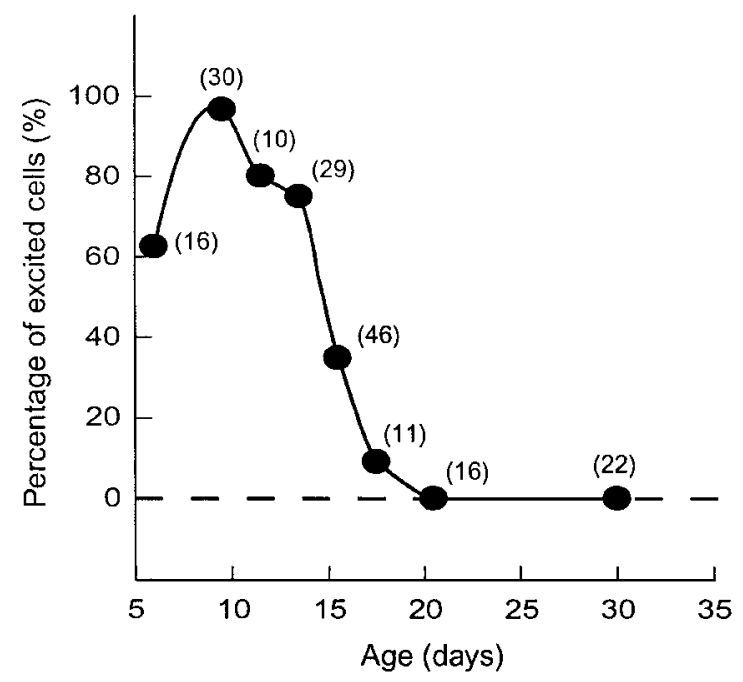

Figure 2. Developmental decline of 5-HT-induced excitatory responses. A, Effects of 5-HT application on membrane potential in layer V pyramidal neurons at P6, P14, P21, and P30. In this and the following figures, action potentials are truncated for clarity. $B$, Histogram showing the percentage of cells that showed tonic firing (excited cells) in response to 5 -HT application at various ages (days after birth). The total number of cells tested at each age is indicated in round brackets. The dashed line indicates $0 \%$.

adult rats. This is consistent with the results obtained in previous studies of adult rat PFC (Araneda and Andrade, 1991; Tanaka and North, 1993).

Postsynaptic mechanisms are responsible for 5-HT-induced excitation

In pyramidal neurons of the adult PFC, activation of $5-\mathrm{HT}_{2 \mathrm{~A}}$ receptors produces a substantial increase in spontaneous ex-
A
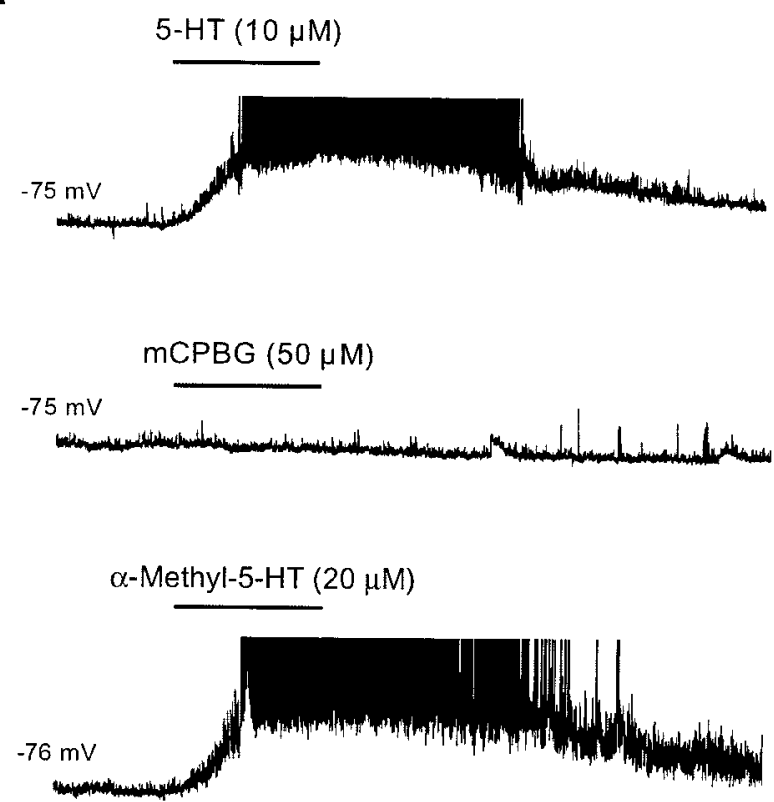

B

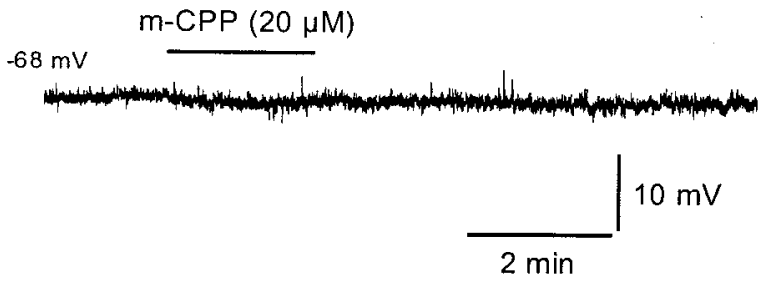

Figure 3. Effects of some 5-HT agonists on membrane potential during early life. A, $\alpha$-methyl-5-HT (bottom trace) mimicked the effects of 5-HT (top trace) in a neuron at P13, whereas $\mathrm{mCPBG}$ (middle trace) had little effect. 5-HT was applied first, followed by mCPBG and then $\alpha$-methyl-5-HT, each separated by a 20 min wash. $B, \mathrm{~m}$-CPP had little effect on membrane potential of a neuron recorded at $\mathrm{P} 12$.

citatory synaptic transmission (Aghajanian and Marek, 1997; Lambe et al., 2000). Therefore, I examined the contribution of presynaptic and postsynaptic effects to 5-HT-induced excitatory responses in neurons aged $\mathrm{P} 10-\mathrm{P} 12$. As illustrated in Figure $5 A, 5$-HT $(10 \mu \mathrm{M})$ elicited an inward current at -74 $\mathrm{mV}(-28 \pm 4 \mathrm{pA} ; n=6)$, accompanied by a substantial increase in noise. After blocking synaptic transmission with ACSF containing $0 \mathrm{Ca}^{2+}$ (nominal) and $8 \mathrm{~mm} \mathrm{Mg}^{2+}, 5-\mathrm{HT}(10$ $\mu \mathrm{M})$ induced an inward current $(-34 \pm 8 \mathrm{pA} ; n=4)$ (Fig. $5 B)$ with little increase in noise. Similar results were obtained when TTX $(0.3 \mu \mathrm{M})$ was included in the ACSF $(-33 \pm 4 \mathrm{pA}$; $n=16$ ) (Fig. 5C). These results suggest that the inward current is the result of a direct postsynaptic action of 5-HT on these neurons, whereas the increase of noise is primarily attributable to presynaptic effects. As shown in previous studies (Aghajanian and Marek, 1997; Zhou and Hablitz, 1999), this increase of spontaneous EPSCs was blocked by the antagonists of glutamate receptors, DNQX $(20 \mu \mathrm{M})$ and D-APV $(50 \mu \mathrm{M}$; $n=5$; data not shown). However, 5-HT-induced excitatory 
A
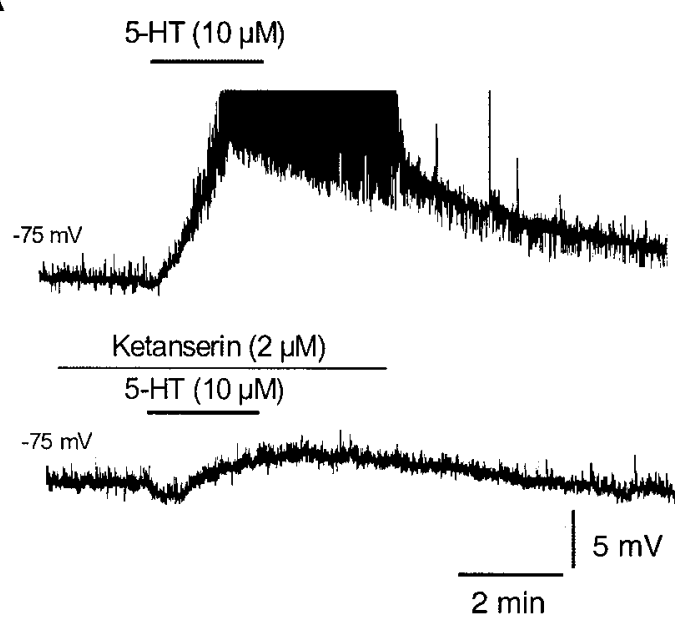

B
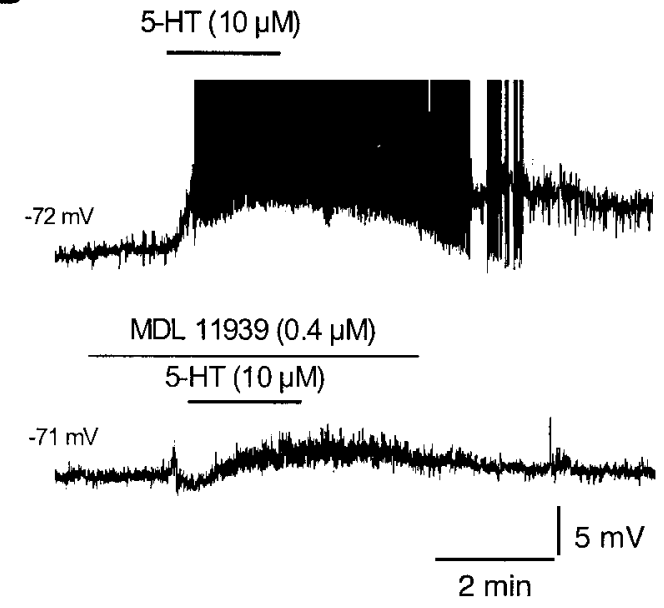

C
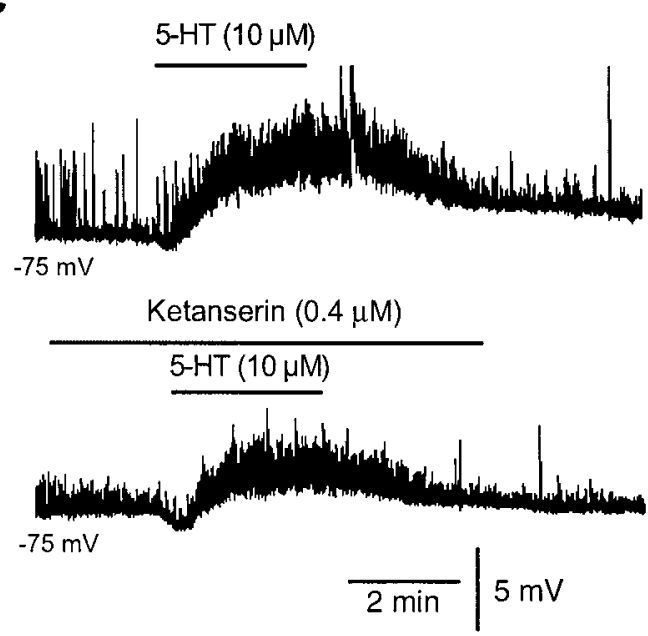

Figure 4. $\quad A, B$, Blockade of 5-HT-induced excitatory effects by $5-\mathrm{HT}_{2 \mathrm{~A}}$ antagonists ketanserin $(A)$ and MDL11939 (B) in two neurons recorded at P13. Cells were allowed to recover completely from the first 5-HT application before testing the antagonists. C, Ketanserin reduces 5-HT-induced depolarization in a neuron at P22. In this cell, $5-\mathrm{HT}(10 \mu \mathrm{m}$ ) induced a depolarization of $4.8 \mathrm{mV}$ (top trace), and in the presence of ketanserin, the response was reduced to $2.3 \mathrm{mV}$ (bottom trace).

responses persisted in the presence of DNQX and D-APV $(n=$ 5) (Fig. 5D). Together, these results suggest that the excitation induced by $5-\mathrm{HT}$ is mediated primarily via postsynaptic mechanisms.
A

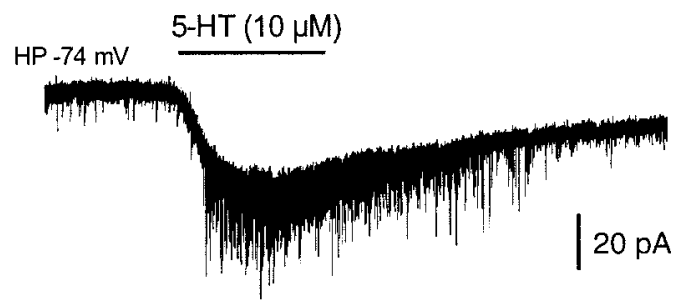

B

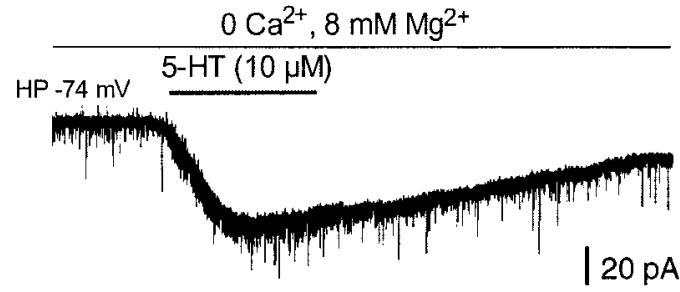

C

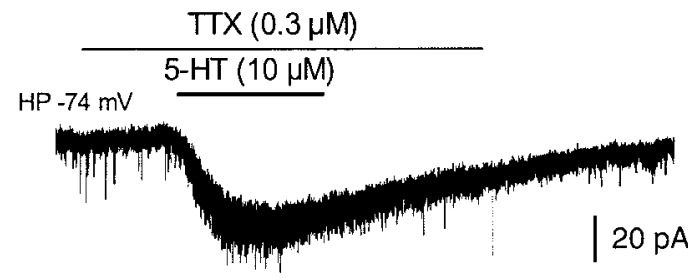

D

$\operatorname{DNQX}(20 \mu \mathrm{M})+\mathrm{D}-\mathrm{AP} 5(50 \mu \mathrm{M})$ $5-\mathrm{HT}(10 \mu \mathrm{M})$

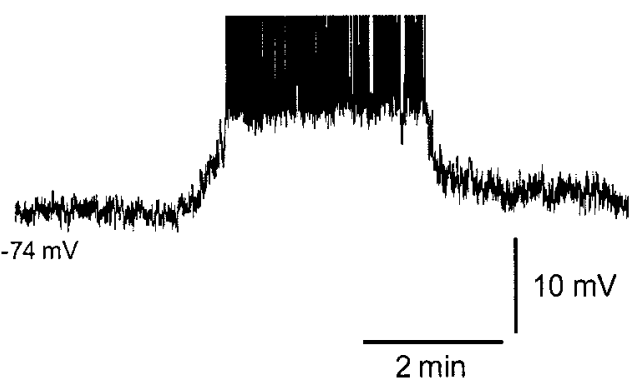

Figure 5. Postsynaptic mechanisms mediate 5 -HT-induced excitatory effects. $A$, Whole-cell currents induced by $5-\mathrm{HT}(10 \mu \mathrm{m})$ in a P10 neuron voltage-clamped at $-74 \mathrm{mV}$. HP, Holding potential. B, 5-HT-induced whole-cell currents in ACSF containing $0 \mathrm{Ca}^{2+}$ and $8 \mathrm{~mm} \mathrm{Mg}^{2+}$ in a P10 neuron. C, 5-HT-induced whole-cell currents in the presence of TTX $(0.3 \mu \mathrm{M})$ in a P10 neuron. D, 5-HT-induced excitatory effects in the presence of DNQX and D-AP5 in a P9 neuron.

Multiple membrane conductances are involved in 5-HT-induced excitation

To determine membrane conductances involved in 5-HTinduced postsynaptic responses, I made voltage-clamp recordings from neurons aged between P10 and P14. TTX $(0.3 \mu \mathrm{M})$ was present throughout the recording to block voltage-gated $\mathrm{Na}^{+}$ channels and 5-HT-induced presynaptic effects (Aghajanian and Marek, 1997; Zhou and Hablitz, 1999). Input resistance was measured by stepping from -60 to -90 or $-120 \mathrm{mV}$. 5-HT $(10 \mu \mathrm{M})$ produced no significant change in input resistance of neurons 
A
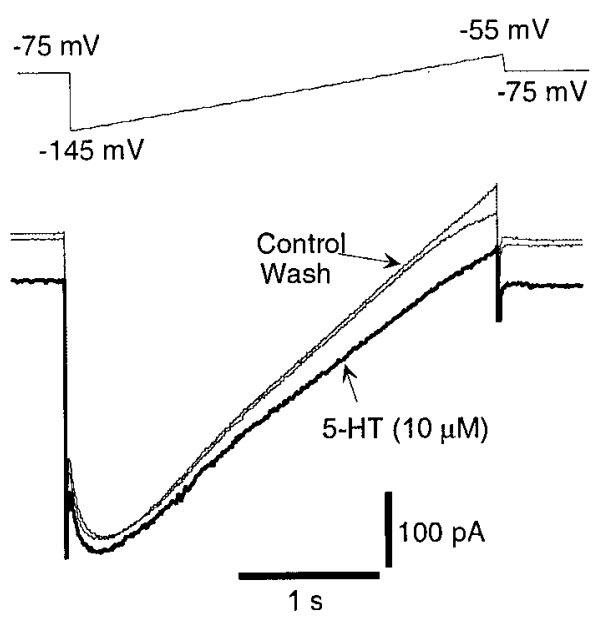

B

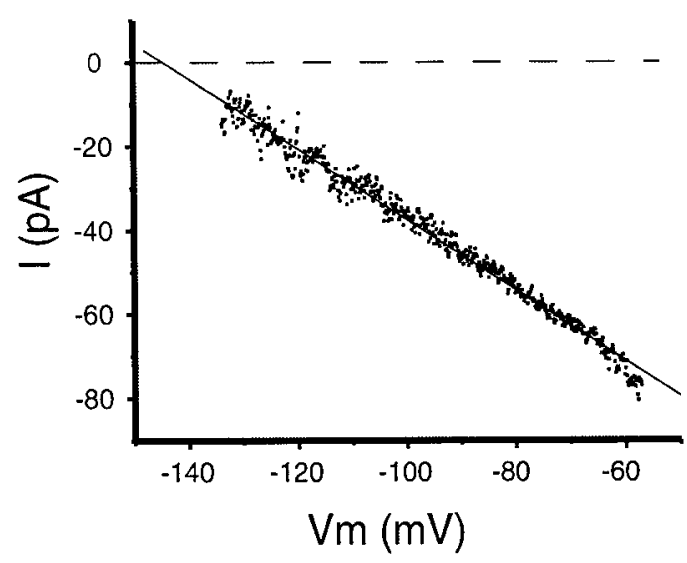

Figure 6. $\quad I-V$ relationship of 5-HT-induced whole-cell currents. $A$, Whole-cell currents in response to a voltage ramp (top trace) before (control, thin trace indicated by an arrow), during (5-HT, bold trace indicated by an arrow), and 10 min after (wash, thin trace, unlabeled) 5-HT application (10 $\mu \mathrm{m}, 2 \mathrm{~min}$ ) in a neuron at P10. Ramps were applied at 20 sec intervals, and each trace was the average of three to four consecutive ramp responses. TTX $(0.3 \mu \mathrm{m})$ was present throughout the recording. Data were filtered at $100 \mathrm{~Hz}$ and digitized at $250 \mathrm{~Hz}$. The dashed line indicates $0 \mathrm{pA}$. $B, I-V$ relationship obtained by subtracting the control currents from those during 5-HT application. Data were fitted by a linear regression line $\left(R^{2}=0.98\right)$. The estimated reversal potential was $-145 \mathrm{mV}$ as determined by extrapolation. $V_{m}$, Membrane potential.

$(2.1 \pm 1.4 \% ; n=16 ; p>0.1)$. To examine the $I-V$ relationship of 5 -HT-induced inward current, slow voltage ramps from -145 to $-55 \mathrm{mV}$ were applied before, during, and after 5-HT application (Fig. 6A). Subtracting currents for the control from those during 5 -HT application yielded 5-HT-induced currents at various membrane potentials. As illustrated in Figure $6 B$, the currents decreased with hyperpolarization but did not reverse at the membrane potential range examined ( -145 to $-55 \mathrm{mV})$. Data can be fitted reliably by a linear regression line, and through extrapolation, the reversal potential was estimated to be $-145 \mathrm{mV}$. Similar results were obtained from eight other cells, and the mean estimated reversal potential was $-148 \pm 3 \mathrm{mV}(n=9)$. This value is far from the equilibrium potentials calculated for $\mathrm{K}^{+}\left(E_{\mathrm{K}},-95\right.$ $\mathrm{mV})$ or $\mathrm{Cl}^{-}(-54 \mathrm{mV})$.

Taking into account the lack of effect by 5-HT on input resistance, one possibility is that 5-HT produces two different changes in membrane conductance: (1) a reduction of outward currents that are normally open at resting potentials (RPs), therefore likely of $\mathrm{K}^{+}$, and (2) an activation of inward currents that are carried by $\mathrm{Na}^{+}$, presumably via cation nonspecific channels that have a reversal potential near $0 \mathrm{mV}$. This hypothesis clearly explains the effects (or the lack of) of 5-HT on input resistance because the two actions of 5-HT produce opposite changes in input resistance, therefore canceling each other. This hypothesis is also consistent with the fact that 5-HT-induced currents did not reverse at membrane potential between $E_{\mathrm{k}}$ and $0 \mathrm{mV}$ (Fig. $6 B$ ), as explained mathematically in an elegant study (Brown et al., 1971).

This hypothesis was examined in several experiments. First, 5 -HT-induced responses were examined in ACSF containing high $\mathrm{K}^{+}$(7 $\mathrm{mm}$ instead of $\left.3 \mathrm{~mm}\right)$, and the $I-V$ relationship was examined in the presence of TTX $(0.3 \mu \mathrm{M})$ with a ramp protocol (Fig. 7A). As shown in Figure $7 B$, the $I-V$ curve in high $\mathrm{K}^{+}$can be fitted reliably by a linear regression line with a reversal potential of $-112 \mathrm{mV}$. Similar responses were obtained from four cells, and the mean reversal potential was $-125 \pm 2 \mathrm{mV}$. Compared with the estimated reversal potential in normal ASCF $\left(3 \mathrm{~mm} \mathrm{~K}^{+}\right)$ (Fig. $6 \mathrm{~B}$ ), this is a shift of $23 \mathrm{mV}$, close to the predicted shift of 21 $\mathrm{mV}$ for $E_{\mathrm{k}}$. This result suggests that $\mathrm{K}^{+}$conductance is involved in 5-HT-induced responses.

The role of $\mathrm{K}^{+}$conductance was also examined in the second series of experiments in which $\mathrm{Ba}^{2+}(1 \mathrm{mM})$ was included in the ACSF to block $\mathrm{K}^{+}$conductance. In the presence of $\mathrm{Ba}^{2+}(1 \mathrm{~mm})$ and TTX $(0.3 \mu \mathrm{M}), 5-\mathrm{HT}(10 \mu \mathrm{M})$ induced an inward current at $-74 \mathrm{mV}(-24 \pm 2 \mathrm{pA} ; n=6$; P10) that was significantly smaller than the control $(-40 \pm 5 \mathrm{pA} ; n=9$; P10, $p<0.04)$. The responses in the presence of $1 \mathrm{mM} \mathrm{Ba}^{2+}$ were associated with a small decrease of input resistance $(-7.8 \pm 0.9 \% ; n=5 ; p<0.005)$. As illustrated in Figure 7, $C$ and $D$, the current induced by 5 -HT increased with hyperpolarization, with an estimated reversal potential of $11 \mathrm{mV}$. Similar results were obtained from five cells, and the mean estimated reversal potential was $-3 \pm 9 \mathrm{mV}(n=5)$. This result suggests that in addition to a reduction of $\mathrm{K}^{+}$conductance, 5-HT activates a current that reverses near $0 \mathrm{mV}$.

To determine whether a cation nonspecific conductance is involved, 5-HT-induced responses were examined in ACSF containing low $\mathrm{Na}^{+}(26 \mathrm{~mm})$ by replacing $124 \mathrm{~mm} \mathrm{NaCl}$ with equimolar of choline-Cl. At $-74 \mathrm{mV}, 5-\mathrm{HT}(10 \mu \mathrm{M})$ induced an inward current of $-15 \pm 1 \mathrm{pA}(n=6 ; \mathrm{P} 10-\mathrm{P} 13)$, significantly smaller than that obtained with normal $\operatorname{ACSF}(-29 \pm 2 \mathrm{pA} ; n=$ 29; P10-P14, $p<0.03$; unpaired Student's $t$ test). In contrast to the responses in the presence of $\mathrm{Ba}^{2+}, 5$-HT produced a small but significant increase of input resistance in low $\mathrm{Na}^{+}(14 \pm 3 \% ; n=$ $5 ; p<0.02)$. The $I-V$ relationship obtained with a ramp protocol (Fig. 7E) yielded a reversal potential of $-100 \mathrm{mV}$ for 5 -HTinduced currents (Fig. $7 F$ ). Similar results were obtained in five cells, and the mean reversal potential was $-95 \pm 2 \mathrm{mV}(n=5$ cells), close to $E_{\mathrm{K}}(-95 \mathrm{mV})$. This result suggests that in addition to a reduction of $\mathrm{K}^{+}$conductance, 5-HT activates $\mathrm{Na}^{+}$conducting channels in these neurons.

What is the type of cation nonspecific channels that is activated by 5-HT? 5-HT has been shown to enhance the hyperpolarization-activated $\mathrm{Na}^{+} / \mathrm{K}^{+}$current $\left(I_{\mathrm{h}}\right)$ in both neonatal and adult neurons in the brain (McCormick and Pape, 1990a; Larkman and Kelly, 1997). Therefore, I examined the role of $I_{\mathrm{h}}$ in 5-HT-induced excitatory effects in three types of experiments. First, I examined the effect of the selective blocker of $I_{\mathrm{h}}$, ZD 7288, on the $I-V$ relationship of 5-HT-induced responses. ZD 7288 at $50 \mu \mathrm{M}$ abolished $I_{\mathrm{h}}$ in these neurons ( $n=8$ cells; data not shown). As illustrated in Figure 8, $A$ and $B, 5$-HT-induced currents in the 
A

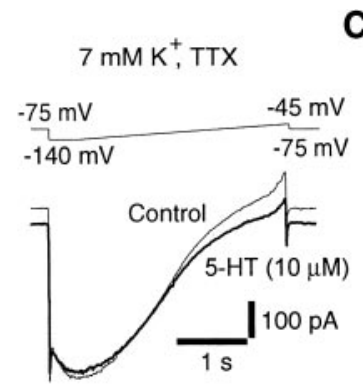

B

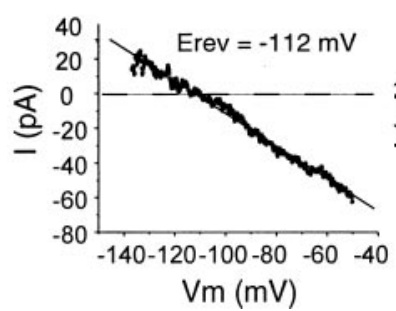

D

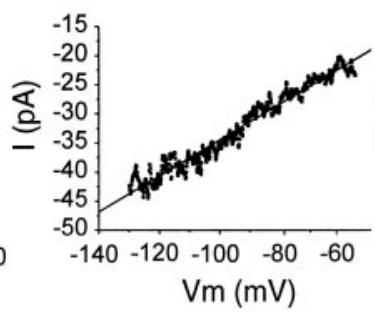

Figure 7. Ionic basis of 5-HT-induced excitatory responses. $A, B, I-V$ relationship of 5-HT-induced currents obtained in ACSF containing high $\mathrm{K}^{+}(7 \mathrm{~mm})$ and $\operatorname{TTX}(0.3 \mu \mathrm{m})$ from a neuron at P13. Data were fitted by a linear regression line $\left(R^{2}=0.91\right)$, and the reversal potential was $-125 \mathrm{mV} . A, C, E$, The top trace indicates the voltage ramp protocols, and the bottom traces are whole-cell currents recorded before (control, thin trace) and during 5-HT application (5-HT, thick trace). C, D, I-V relationship of 5-HT-induced currents obtained in ACSF containing Ba ${ }^{2+}(1 \mathrm{~mm})$ and TTX $(0.3 \mu \mathrm{m})$ from a neuron at P10. Data were fitted by a linear regression line $\left(R^{2}=0.96\right)$ with an estimated reversal potential of $11 \mathrm{mV}$. E, F, I-V relationship of 5-HT-induced currents obtained in ACSF containing $124 \mathrm{~mm}$ choline-Cl from a neuron at P13. The reversal potential, $-100 \mathrm{mV}$, was determined by line fitting $\sim 100$ data points $\sim 0 \mathrm{pA}$.

presence of ZD $7288(50 \mu \mathrm{M})$ reversed at $-108 \mathrm{mV}$, near $E_{\mathrm{k}}(-95$ $\mathrm{mV})$. The mean reversal potential in $\mathrm{ZD} 7288$ was $-112 \pm 4 \mathrm{mV}$ ( $n=4$ cells; P11-P12), a shift of $36 \mathrm{mV}$ compared with the estimated reversal potential for the control, indicating that $I_{\mathrm{h}}$ is involved in 5-HT-induced excitatory effects. In the second experiment, the effect of 5-HT on $I_{\mathrm{h}}$ was examined directly. As shown in Figure $8 C$, neurons were voltage-clamped at $-55 \mathrm{mV}$, and $I_{\mathrm{h}}$ was activated by stepping to $-95 \mathrm{mV}$ for $2 \mathrm{sec} . I_{\mathrm{h}}$, measured as the difference between the onset of $I_{\mathrm{h}}$ and the end of the voltage step (Fig. 8C, dashed lines $A$ and $B$ ), was relatively small at ages P10$\mathrm{P} 13$, with a mean amplitude of $55 \pm 8 \mathrm{pA}$ ( $n=15$ cells $) .5$-HT ( 10 $\mu \mathrm{M})$ reversibly enhanced $I_{\mathrm{h}}$ by $14 \pm 3 \mathrm{pA}$ or $35 \pm 6 \%(n=10$ cells). Finally, using current-clamp recording, I examined whether $I_{\mathrm{h}}$ is required for 5-HT-induced excitation. As shown in Figure $8 D$, ZD $7288(50 \mu \mathrm{M})$, which itself induced a small hyperpolarization, had little effect on 5-HT-induced depolarization and tonic firing in a P12 neuron. Similar results were obtained in all four cells tested. In several experiments, I also used low concentrations of $\mathrm{Cs}^{+}$to block $I_{\mathrm{h}}$. As shown previously (McCormick and Pape, 1990b), $1 \mathrm{mM} \mathrm{Cs}^{+}$in the bath abolished $I_{\mathrm{h}}$ in all cells tested ( $n=5$; data not shown). However, for ZD 7288, $1 \mathrm{~mm} \mathrm{Cs}^{+}$ had little effect on 5-HT-induced depolarization and tonic firing in neurons at $\mathrm{P} 10$ ( $n=3$; data not shown). Together, these results suggest that although an enhancement of $I_{\mathrm{h}}$ by 5 -HT contributes to 5-HT-induced excitatory effects, its role is secondary.

To examine the voltage dependence and time course of the inhibitory effect of 5 -HT on $\mathrm{K}^{+}$channels, I compared, in the same cells, $I-V$ relationships obtained with voltage ramps of different rates. ZD $7288(50 \mu \mathrm{M})$ was used in these experiments to block $I_{\mathrm{h}}$, and TTX $(0.3 \mu \mathrm{M})$ was also included in the bath. The results are illustrated in Figure 9. The data obtained with the fast ramp $(400 \mathrm{mV} / \mathrm{sec})$ (Fig. $9 A)$ showed a linear $I-V$ relationship between -125 and $-60 \mathrm{mV}$, with a reversal potential of -109
$\mathrm{mV}$ (Fig. 9C, open circles). This is comparable with the results obtained with the slow ramp (27 mV/sec) (Fig. 9B), which had a reversal potential of $-112 \mathrm{mV}$ (Fig. $9 C$, filled triangles). Similar results were obtained from three other cells. The mean reversal potentials for the fast and slow ramps are $-107 \pm 4$ and $-106 \pm 3 \mathrm{mV}$ ( $n=4 ; p>0.5$; fast ramp vs slow ramp), respectively. These values are close to $E_{\mathrm{k}}$ $(-95 \mathrm{mV})$. The mean slopes for the fast and slow ramps, measured by line fitting (Fig. 9C, thin and bold lines), are $-0.36 \pm$ 0.07 and $-0.49 \pm 0.08(n=4 ; p>0.1$; fast ramp vs slow ramp). Together, these results show that the inhibitory effects of 5 -HT on $\mathrm{K}^{+}$conductance are primarily voltage independent between -125 and $-60 \mathrm{mV}$, suggesting the involvement of a leak $\mathrm{K}^{+}$conductance.

\section{Downregulation of 5-HT-induced inward currents and developmental changes of intrinsic properties of pyramidal neurons}

Four types of experiments were performed to examine the mechanisms underlying the decline of 5-HT-induced excitatory responses during postnatal development.

Besides its action on excitatory transmission, 5-HT, through $5-\mathrm{HT}_{2 \mathrm{~A}}$ receptors, has been shown to enhance spontaneous GABAergic synaptic transmission in pyramidal neurons in the PFC (Zhou and Hablitz, 1999; Foehring et al., 2002). To determine whether an upregulation of GABAergic inhibition is responsible for the developmental decline of 5-HTinduced excitatory effects, the effect of bicuculline was examined in neurons aged P22-P23. In the presence of $(-)$-bicuculline methiodide $(10 \mu \mathrm{M}), 5$-HT $(10 \mu \mathrm{M})$ induced a small depolarization with a mean amplitude of $2.8 \pm 1 \mathrm{mV}(n=4$ cells $)$, similar to the control responses obtained during the same period (P21; $2.8 \pm 0.3 \mathrm{mV} ; n=8$ cells $)$. In these experiments, DNQX $(20 \mu \mathrm{M})$ was included in the bath to prevent bicuculline-induced seizure in the slices. DNQX by itself did not block the 5-HT-induced increase of spontaneous GABAergic transmission $(n=5$ cells; data not shown) and had little effect on 5-HT-induced depolarization (Fig. 5D). These results suggest that GABAergic inhibition is not involved in the decline of 5-HT-induced excitatory responses during development.

In the second experiment, I examined whether an upregulation of $5-\mathrm{HT}_{1 \mathrm{~A}}$ is involved. In the presence of the $5-\mathrm{HT}_{1 \mathrm{~A}}$ antagonist NAN-190 $(0.5 \mu \mathrm{M}), 5-\mathrm{HT}(10 \mu \mathrm{M})$ induced only a small depolarization ( $2.6 \pm 1.7 \mathrm{mV} ; n=3$, data not shown) without firing at P29-P31. Moreover, in neurons aged P18/19, the specific agonist for $5-\mathrm{HT}_{2}$ receptors, $\alpha$-methyl-5-HT (40 $\left.\mu \mathrm{M}\right)$, produced moderate depolarization without cell firing $(2.1 \pm 0.6 \mathrm{mV}$; $n=6$; data not shown). This is similar to the responses by $5-\mathrm{HT}$ during the same period but drastically different from responses by $\alpha$-methyl-5-HT $(20 \mu \mathrm{M})$ in neurons at earlier ages (P9-P14) in which large depolarization and tonic firing were observed in all cells tested $(n=5)$ (Fig. $3 A$ ). Together, these results suggest that a downregulation of $5-\mathrm{HT}_{2}$ receptor function may be the key reason for the decline of 5-HT-induced excitatory effects. 
Next, I examined directly 5-HTinduced inward currents during development. TTX $(0.3 \mu \mathrm{M})$ was used to block presynaptic effects of 5-HT, and NAN$190(2 \mu \mathrm{M})$ was used to block $5-\mathrm{HT}_{1 \mathrm{~A}}$ receptors. The results are summarized in Figure $10 \mathrm{~A}$. At P10/11, 5-HT $(10 \mu \mathrm{M})$ induced an inward current of $-33 \pm 4 \mathrm{pA}$ $(n=16)$ at $-74 \mathrm{mV}$. This response remained unchanged at P14 $(-27 \pm 6 \mathrm{pA}$; $n=6 ; p>0.4)$ and then decreased by $\sim 50 \%$ by P21 $(-14 \pm 2 \mathrm{pA} ; n=6 ; p<$ 0.01 vs $\mathrm{P} 10 / 11)$ and remained stable at $\mathrm{P} 31(-12 \pm 1 \mathrm{pA} ; n=5 ; p>0.6$ vs P21).

Last, I examined whether changes in intrinsic properties may contribute to the decline of 5-HT-induced excitatory responses. Input resistance $\left(R_{\mathrm{m}}\right), \mathrm{RP}$, and spike threshold were measured for the period between P6 and P31. The most striking change was observed for $R_{\mathrm{m}}$ (Fig. $10 B)$. For example, between P10 and P21, $R_{\mathrm{m}}$ decreased by $75 \%$, from $463 \pm 36 \mathrm{M} \Omega$ $(n=14)$ to $116 \pm 10 \mathrm{M} \Omega(n=19 ; p<$ $0.001)$. During the same period, cells became more hyperpolarized, with RP of $-71 \pm 1 \mathrm{mV}(n=14)$ at P10 and $-77 \pm$ $1 \mathrm{mV}$ at P21 $(n=19 ; p<0.001)$. However, the spike threshold also lowered, and the difference between spike threshold and RP ( $\left.\delta V_{\text {Thres-RP }}\right)$ remained relatively stable throughout the period between P6 and P31 ( $p>0.1$ between any two values) (Fig. 10C). These results suggest that the decline of 5-HT-induced excitatory responses is in part caused by a decrease of $R_{\mathrm{m}}$ during development.

\section{Discussion}

This study showed that 5-HT, acting through $5-\mathrm{HT}_{2 \mathrm{~A}}$ receptors, induced tonic firing in layer $\mathrm{V}$ pyramidal neurons during postnatal development. The excitatory effects of 5-HT were predominantly postsynaptic and implicated multiple membrane conductances. 5-HT-induced excitatory responses decreased rapidly after P14, reaching the adult level by the end of the third week. These results suggest a role for 5-HT in activity-dependent processes during postnatal development of the PFC.

\section{Excitatory effects of 5-HT during postnatal development}

Bath application of 5-HT induced a slow depolarization followed by a period of tonic firing in the majority of neurons recorded between P6 and P14 (Figs. 1, 2). Similar responses have been observed in the brainstem, hypothalamus, and medulla of neonatal or juvenile rats (Wang and Dun, 1990; Talley et al., 1997; Eriksson et al., 2001).

The excitatory effects of 5-HT declined dramatically after P14, and by P21, 5-HT produced little effect on membrane potential (Fig. 2). These results are consistent with previous studies in the
A

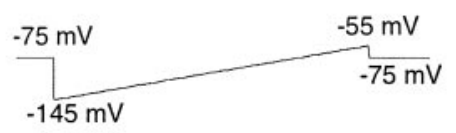

C
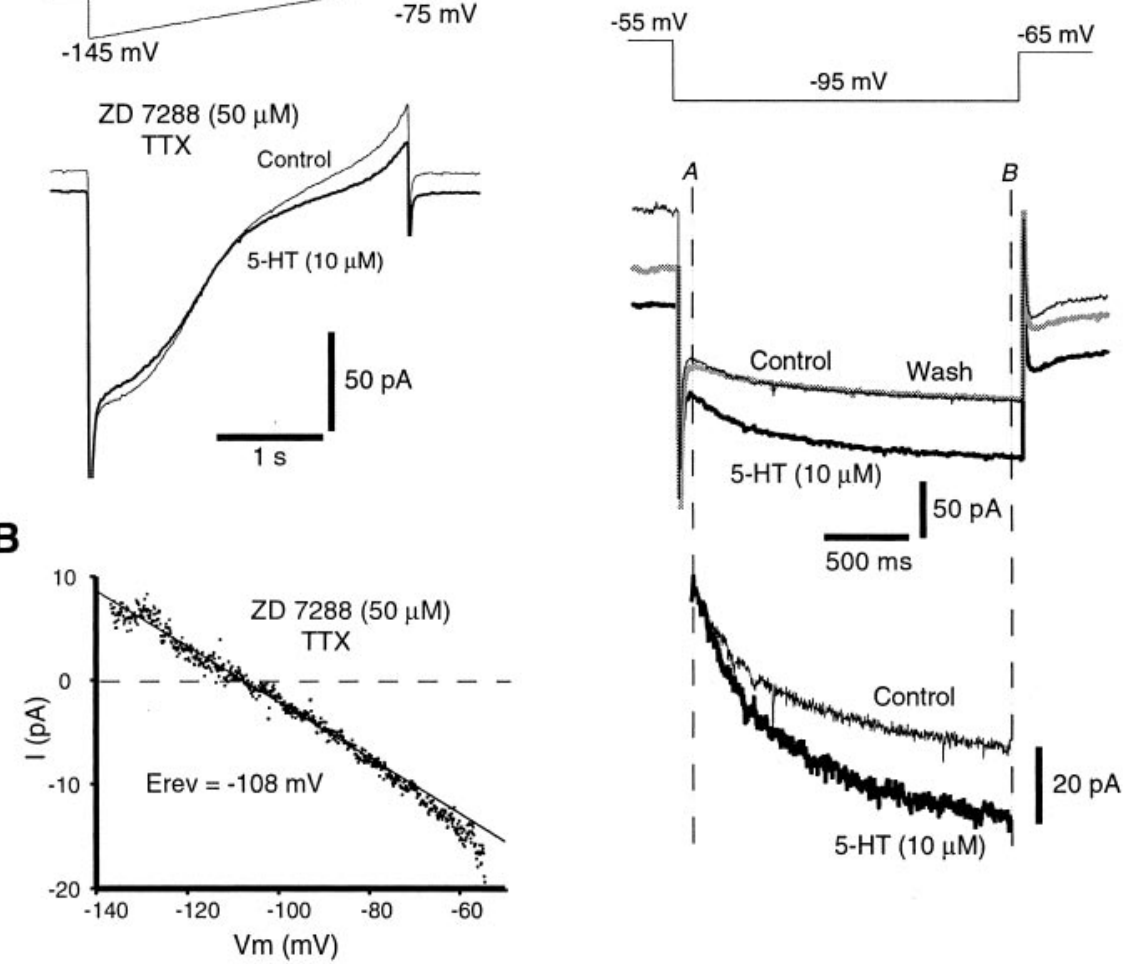

Figure 8. Enhancement of $/ \mathrm{h}$ by 5 -HT contributes to 5 -HT-induced responses. $A$, Whole-cell currents in the presence of ZD $7288(50 \mu \mathrm{M})$ and $T \mathrm{TX}(0.3 \mu \mathrm{m})$ responding to a voltage ramp (top panel; the same as in Fig. $6 \mathrm{~A}$ ) before (control, thin trace) and during (5-HT, bold trace) 5-HT application $(10 \mu \mathrm{M})$ in a neuron at P12. B, I-V relationship of 5-HT-induced currents in the presence of ZD $7288(50 \mu \mathrm{M})$. Data were fed by a linear regression line $\left(R^{2}=0.97\right)$, and the reversal potential was $-108 \mathrm{mV} . C, 5-\mathrm{HT}$ reversibly enhances $I_{\mathrm{h}}$ in a P10 neuron. The top trace illustrates the voltage step used to activate $I_{h}$. The middle traces show whole-cell currents before (control, thin trace), during (5-HT, bold trace), and 5 min after (wash, bold gray trace) bath application of 5-HT $(10 \mu \mathrm{M})$. TTX $(0.3 \mu \mathrm{M})$ was present throughout the recording eottom traces show the difference in $I_{\mathrm{h}}$ between the control and that during $5-\mathrm{HT}$ application by normalizing the responses at the -induced excitatory responses in the presence of ZD 7288. ZD $7288(50 \mu \mathrm{m})$ by itself induced a hyperpolarization of approximately $-2 \mathrm{mV}$ but did not block 5 -HT-induced depolarization and tonic firing in a neuron at P12.
PFC of young adult (P20-P30) and adult rats, in which 5-HT induced either moderate hyperpolarization or small depolarization without cell firing (Araneda and Andrade, 1991; Tanaka and North, 1993). This developmental decline in 5-HT-induced responses, however, was not observed in other parts of the brain. Thus, in the brainstem and hypothalamus of young adult (P20P30) or adult rats, 5-HT still induced large depolarization and cell firing (Talley et al., 1997; Eriksson et al., 2001), suggesting that although 5-HT is widely involved in brain development, its actual role may vary from one region to another. 


\section{A} ZD $7288(50 \mu \mathrm{M})$, TTX $(0.3 \mu \mathrm{M})$

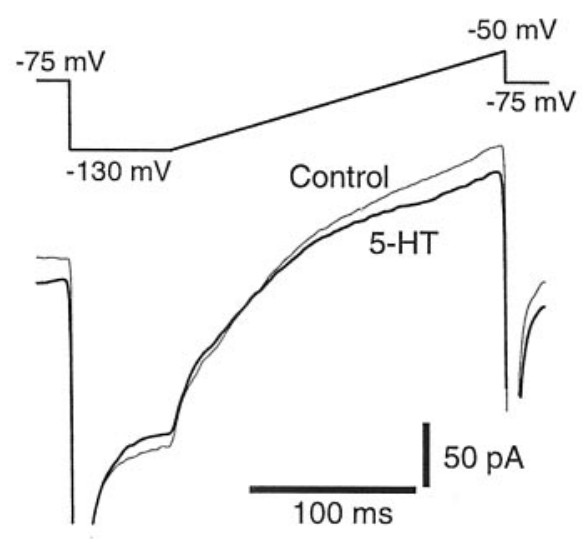

B
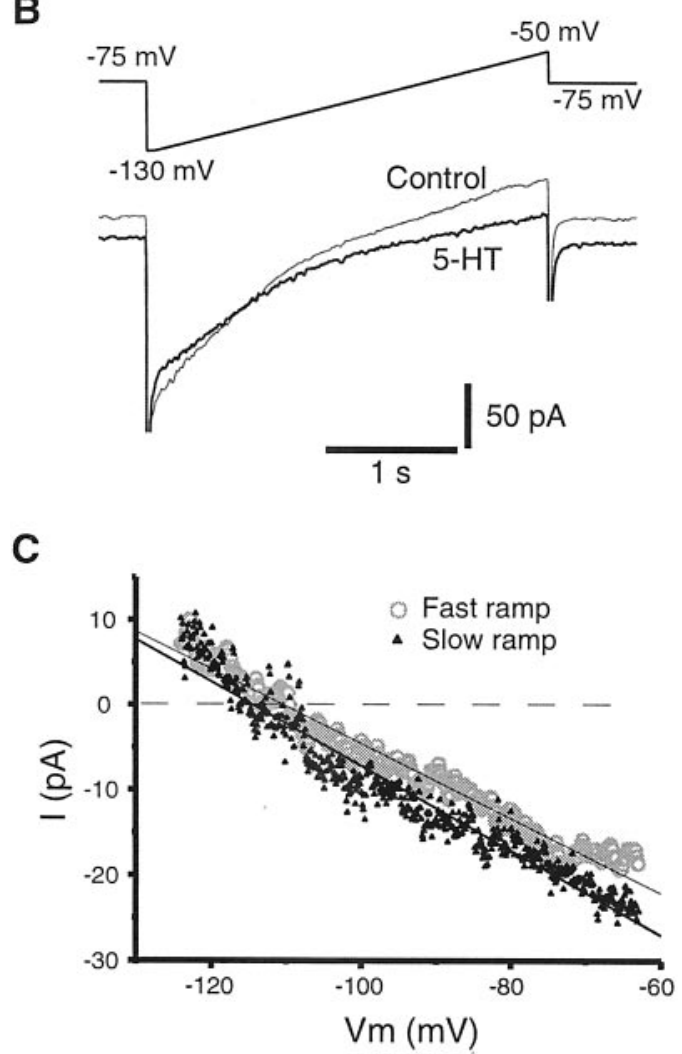

Figure 9. I-V relationship of 5-HT-induced currents examined using ramps of two different rates in a neuron at P12. TTX $(0.3 \mu \mathrm{m})$ was present throughout the recording. ZD $7288(50 \mu \mathrm{m})$ was used to block $I_{\mathrm{h}} . A, B$, Top traces show ramp protocols, and bottom traces show currents obtained before (thin lines, control) and during (bold lines, 5-HT) 5-HT application. In both $A$ and $B$, the cell was stepped to $-130 \mathrm{mV}$ for $80 \mathrm{msec}$ before the beginning of ramps. The rates of ramps are 400 and $27 \mathrm{mV} / \mathrm{sec}$ for $A$ and $B$, respectively. Data were filtered at $100 \mathrm{~Hz}$. C, I-V relationship obtained from data presented in $A$ (open circles, fast ramp) and $B$ (filled triangles, slow ramp). Both groups of data can be fitted by linear regression lines with slopes of -0.44 $\left(R^{2}=0.966\right)$ and $-0.50\left(R^{2}=0.941\right)$ for the fast (thin line) and slow (bold line) ramps, respectively. The reversal potentials are -109 and $-112 \mathrm{mV}$ for the fast and slow ramps, respectively.

5- $\mathrm{HT}_{2 \mathrm{~A}}$ receptors mediated the excitatory effects of 5-HT

Several subtypes of 5-HT receptors have been implicated in excitatory effects induced by $5-\mathrm{HT}$. These include $5-\mathrm{HT}_{2 \mathrm{~A}}$ receptors in the brainstem and medulla (Talley et al., 1997; Hwang and Dun, 1998), 5- $\mathrm{HT}_{2 \mathrm{C}}$ receptors in the hypothalamus (Eriksson et
A

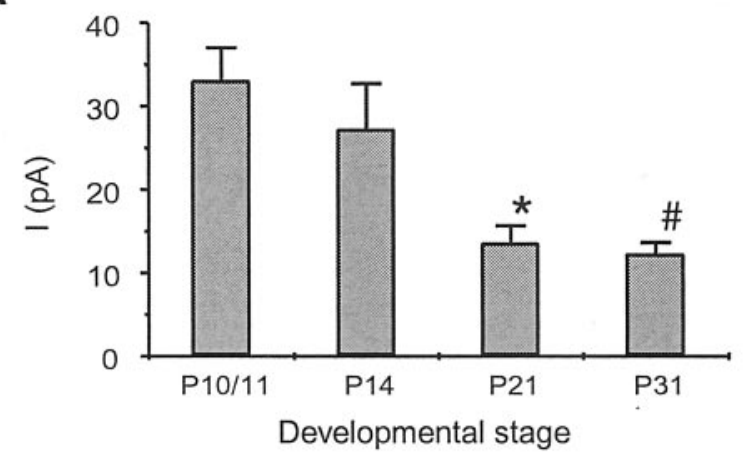

B
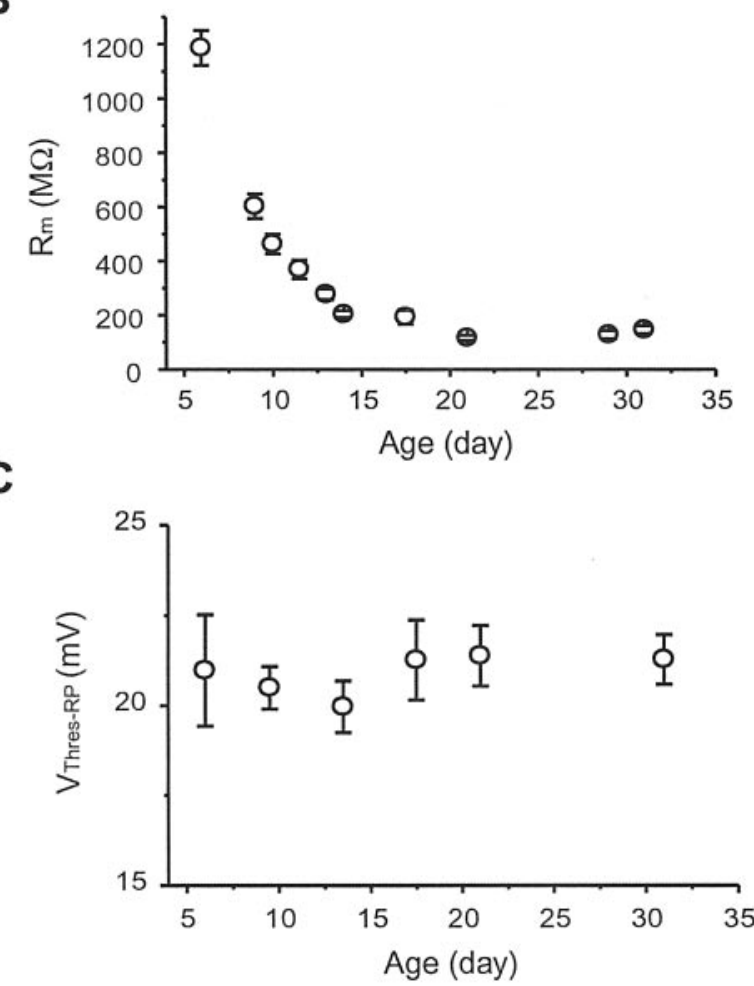

Figure 10. Downregulation of 5-HT-induced inward currents and developmental changes of intrinsic properties. A, Decline of 5-HT-induced inward currents during postnatal development. The presynaptic effects of 5 - HT were blocked by TTX $(0.3 \mu \mathrm{m})$ and $5-\mathrm{HT}_{1 \mathrm{~A}}$ receptor function by NAN-190 (2 $\mu \mathrm{M}) .{ }^{*} p<0.01$ versus P10/11; ${ }^{*} p>0.5$ versus P21; two-tailed Student's $t$ test. $B$, Decrease in membrane resistance $\left(R_{\mathrm{m}}\right)$ during postnatal development. $C$, The difference in voltage between spike threshold and resting potential ( $\left.\delta V_{\text {Thres-RP }}\right)$ measured at various ages.

al., 2001), and $5-\mathrm{HT}_{3}$ receptors in the amygdala and developing visual cortex (Sugita et al., 1992; Roerig et al., 1997). The excitatory effects of 5-HT in the developing PFC were mimicked by the $5-\mathrm{HT}_{2}$ agonist $\alpha$-methyl-5-HT, but not the $5-\mathrm{HT}_{3}$ agonist $\mathrm{mCPBG}$ or the $5-\mathrm{HT}_{2 \mathrm{~B} / 2 \mathrm{C}}$ agonist $\mathrm{m}-\mathrm{CPP}$, and blocked by two different $5-\mathrm{HT}_{2 \mathrm{~A}}$ antagonists, ketanserin and MDL 11939, suggesting a predominant role for $5-\mathrm{HT}_{2 \mathrm{~A}}$ receptors. However, these data also suggest a minor contribution by other 5-HT receptors because neither ketanserin nor MDL 11939 completely abolished 5-HT-induced depolarization. Two recent studies showed that $5-\mathrm{HT}_{7}$ receptors, acting on $I_{\mathrm{h}}$, mediated the excitatory effects of 5-HT in thalamic neurons of young adult rats (Chapin and Andrade, 2001a,b). Whether 5-HT-induced excitatory responses in the $\mathrm{PFC}$ also involve $5-\mathrm{HT}_{7}$ receptors requires additional examination using highly selective drugs. 
Another caveat is associated with the method of drug application. Other studies have shown that $5-\mathrm{HT}_{3}$ receptors desensitize within seconds (Yakel and Jackson, 1988; Yang et al., 1992). It is therefore possible that the slow bath application used here failed to produce a detectable $5-\mathrm{HT}_{3}$ response. Fast application methods will help to clarify this point.

\section{Postsynaptic mechanisms underlying 5-HT-induced excitatory effects}

Activation of $5-\mathrm{HT}_{2 \mathrm{~A}}$ receptors increases spontaneous excitatory transmission in many parts of the brain (Marek and Aghajanian, 1998). Although the precise mechanisms remain unclear, evidence implicates presynaptic depolarization because the effects are blocked by TTX or in $0 \mathrm{Ca}^{2+}$ and high $\mathrm{Mg}^{2+}$ (Wang and Dun, 1990; Aghajanian and Marek, 1997). Similar presynaptic effects were observed here in the developing PFC. However, blocking synaptic transmission produced little effect on 5-HT-induced inward currents or membrane depolarization (Fig. 5). These results are consistent with previous studies in the medulla and brainstem (Berger et al., 1992; Hwang and Dun, 1998), suggesting that postsynaptic, not presynaptic, mechanisms are responsible for 5-HT-induced excitatory responses.

Multiple conductances are involved in 5-HT-induced excitatory responses. At RP, 5-HT induced an inward current with little change in $R_{\mathrm{m}}$, and the response showed little voltage dependence, with an estimated $E_{\text {rev }}$ of $-148 \mathrm{mV}$ (Fig. $6 \mathrm{~B}$ ), far from equilibrium potentials for any major physiological ions. These observations are in line with those obtained in other parts of the brain (Berger et al., 1992; Hwang and Dun, 1998). One possibility is that 5-HT may cause both a decrease of $\mathrm{K}^{+}$conductance and an increase of cation nonspecific conductance (Hwang and Dun, 1999). This hypothesis is supported by these data showing that (1) substitution of external $\mathrm{Na}^{+}$with choline shifted $E_{\text {rev }}$ close to $E_{\mathrm{k}}$ (Fig. $7 F$ ), associated with an increase in $R_{\mathrm{m}}$, (2) blocking $\mathrm{K}^{+}$ conductance with $\mathrm{Ba}^{2+}$ shifted $E_{\text {rev }}$ close to $0 \mathrm{mV}$ (Fig. $7 D$ ), together with a decrease in $R_{\mathrm{m}}$, and (3) raising $\left[\mathrm{K}^{+}\right]_{\mathrm{o}}$ to $7 \mathrm{mM}$ shifted $E_{\text {rev }}$ by $23 \mathrm{mV}$ (Fig. $7 B$ ), close to the shift in $E_{\mathrm{k}}$.

Several studies have shown that an enhancement of $I_{\mathrm{h}}$ underlies 5-HT-induced slow depolarization (McCormick and Pape, 1990a; Larkman and Kelly, 1997). $I_{\mathrm{h}}$ deactivates slowly and has a near-linear instantaneous $I-V$ relationship, with a reversal potential near $-20 \mathrm{mV}$. The involvement of $I_{\mathrm{h}}$ was supported by the finding that 5-HT significantly enhanced $I_{\mathrm{h}}$ (Fig. $8 C$ ), and that blocking $I_{\mathrm{h}}$ shifted $E_{\text {rev }}$ toward $E_{\mathrm{k}}$ (Figs. $8 A, B, 9 C$ ). The fact that neither ZD7288 nor $\mathrm{Cs}^{+}$blocks 5-HT-induced excitation (Fig. $8 D$ ) suggests that the action of $5-\mathrm{HT}$ on $I_{\mathrm{h}}$ plays a minor role.

Together, these data are in line with previous studies, suggesting that both an inhibition of leak $\mathrm{K}^{+}$conductance and an enhancement of $I_{\mathrm{h}}$ contribute to 5-HT-induced depolarization (Andrade and Nicoll, 1987; McCormick and Pape, 1990a; McCormick and Wang, 1991; Larkman and Kelly, 1998).

This study does not exclude dendritic responses induced by 5-HT. 5- $\mathrm{HT}_{2 \mathrm{~A}}$ receptors are highly expressed in the apical dendrites of these neurons (Cornea-Hebert et al., 1999). Because of space clamp, any effects at distal dendrites are likely to be misrepresented in the voltage-clamp experiments. Thus, the observation that $E_{\text {rev }}$ in ZD7288 is more negative than $E_{\mathrm{k}}$ (Fig. $8 B$ ) can be explained by a reduction of dendritic $\mathrm{K}^{+}$conductance by $5-\mathrm{HT}$. Furthermore, the effects of 5-HT on $I_{\mathrm{h}}$ may be particularly important in the distal apical dendrite, in which the highest density of $I_{\mathrm{h}}$ is found (Berger et al., 2001). Direct recordings from dendrites are required to address these issues.

\section{Developmental decline of the excitatory responses induced by 5 -HT}

These data showed that the percentage of 5-HT-excited cells dropped from $>95 \%$ at $\mathrm{P} 9 / 10$ to $0 \%$ by $\mathrm{P} 21$. Such a dramatic change in 5-HT-induced responses during development has not been reported in other parts of the brain. This decline is not caused by changes in the efficiency of 5-HT as the agonist because at concentrations as high as $100 \mu \mathrm{M}, 5-\mathrm{HT}$ still failed to excite neurons at older ages. The fact that 5-HT-induced hyperpolarization appears progressively during postnatal development suggests an upregulation of $5-\mathrm{HT}_{1 \mathrm{~A}}$ function during early life (Zilles et al., 1985; Gross et al., 2002). However, this possibility is also unlikely to play a major role because blocking $5-\mathrm{HT}_{1 \mathrm{~A}}$ receptors had little effect on 5-HT-induced responses in neurons aged P21 or older. In contrast, the responses to $\alpha$-methyl-5-HT, the 5- $\mathrm{HT}_{2}$ agonist, decreased during early life in a similar way as those to 5-HT. Furthermore, in the presence of NAN-190, 5-HT-induced inward currents decreased significantly between P14 and P21 (Fig. 10A). Thus, these data suggest a developmental decline of $5-\mathrm{HT}_{2 \mathrm{~A}}$ receptor function. In adult rats, layer $\mathrm{V}$ pyramidal neurons express high levels of $5-\mathrm{HT}_{2 \mathrm{~A}}$ receptors (Cornea-Hebert et al., 1999), and little evidence is available for a downregulation of $5-\mathrm{HT}_{2 \mathrm{~A}}$ receptor expression during development. However, the function of $5-\mathrm{HT}_{2 \mathrm{~A}}$ receptors, as measured by phosphoinositide turnover, decreases during early life in the rat brain (Claustre et al., 1988; Ike et al., 1995). Therefore, changes at the level of effectors may underlie the decline of $5-\mathrm{HT}_{2 \mathrm{~A}}$ function.

Another factor involved in the decline of 5-HT-induced excitation is the progressive reduction of $R_{\mathrm{m}}$ during development. Consistent with previous studies (McCormick and Prince, 1987; Burgard and Hablitz, 1993), $R_{\mathrm{m}}$ decreased by $75 \%$ between P10 and P21 (Fig. 10B). Thus, compared with P9/10, much larger currents are required for $\mathrm{P} 21$ neurons to reach the threshold.

\section{Developmental implications of 5-HT-induced excitatory responses}

Previous studies emphasize that the first 2 weeks after birth is the critical period for the development of the neocortex in rodents (O'Leary et al., 1994; Stern et al., 2001). The cortex at birth is primarily undifferentiated, and over the next 2 weeks, the differentiation of neurons and formation of cortical layers occur concomitantly (Rice et al., 1985; Van Eden and Uylings, 1985). This is also a period of intensive synaptogenesis. The density of synapses in the cortex increases fivefold between P10 and P15, approaching the adult level (Micheva and Beaulieu, 1996). Neuronal activities play a critical role in the postnatal development of the neocortex. Disruption of activity during early life causes long-lasting changes in the organization and function of neuronal circuits in the cortex. This study showed a strong excitatory effect of 5-HT during the peak of neuronal differentiation and synaptogenesis in the $\mathrm{PFC}$, suggesting that $5-\mathrm{HT}$, via $5-\mathrm{HT}_{2 \mathrm{~A}}$ receptors, plays an important role in these developmental processes.

\section{References}

Aghajanian GK, Marek GJ (1997) Serotonin induces excitatory postsynaptic potentials in apical dendrites of neocortical pyramidal cells. Neuropharmacology 36:589-599.

Aloyo VJ, Harvey JA (2000) Antagonist binding at 5-HT(2A) and 5-HT(2C) receptors in the rabbit: high correlation with the profile for the human receptors. Eur J Pharmacol 406:163-169.

Andrade R, Nicoll RA (1987) Pharmacologically distinct actions of serotonin on single pyramidal neurones of the rat hippocampus recorded in vitro. J Physiol (Lond) 394:99-124.

Araneda R, Andrade R (1991) 5-Hydroxytryptamine2 and 5-hydroxytryp- 
tamine $1 \mathrm{~A}$ receptors mediate opposing responses on membrane excitability in rat association cortex. Neuroscience 40:399-412.

Azmitia EC (2001) Modern views on an ancient chemical: serotonin effects on cell proliferation, maturation, and apoptosis. Brain Res Bull 56:413-424.

Bennett-Clarke CA, Leslie MJ, Lane RD, Rhoades RW (1994) Effect of serotonin depletion on vibrissa-related patterns of thalamic afferents in the rat's somatosensory cortex. J Neurosci 14:7594-7607.

Berendse HW, Galis-de Graaf Y, Groenewegen HJ (1992) Topographical organization and relationship with ventral striatal compartments of prefrontal corticostriatal projections in the rat. J Comp Neurol 316:314-347.

Berger AJ, Bayliss DA, Viana F (1992) Modulation of neonatal rat hypoglossal motoneuron excitability by serotonin. Neurosci Lett 143:164-168.

Berger T, Larkum ME, Luscher HR (2001) High I(h) channel density in the distal apical dendrite of layer $\mathrm{V}$ pyramidal cells increases bidirectional attenuation of EPSPs. J Neurophysiol 85:855-868.

Brown JE, Muller KJ, Murray G (1971) Reversal potential for an electrophysiological event generated by conductance changes: mathematical analysis. Science 174:318.

Burgard EC, Hablitz JJ (1993) Developmental changes in NMDA and nonNMDA receptor-mediated synaptic potentials in rat neocortex. J Neurophysiol 69:230-240.

Cases O, Vitalis T, Seif I, De Maeyer E, Sotelo C, Gaspar P (1996) Lack of barrels in the somatosensory cortex of monoamine oxidase A-deficient mice: role of a serotonin excess during the critical period. Neuron 16:297-307.

Chapin EM, Andrade R (2001a) A 5-HT(7) receptor-mediated depolarization in the anterodorsal thalamus. I. Pharmacological characterization. J Pharmacol Exp Ther 297:395-402.

Chapin EM, Andrade R (2001b) A 5-HT(7) receptor-mediated depolarization in the anterodorsal thalamus. II. Involvement of the hyperpolarizationactivated current I(h). J Pharmacol Exp Ther 297:403-409.

Claustre Y, Rouquier L, Scatton B (1988) Pharmacological characterization of serotonin-stimulated phosphoinositide turnover in brain regions of the immature rat. J Pharmacol Exp Ther 244:1051-1056.

Conn PJ, Sanders-Bush E (1987) Relative efficacies of piperazines at the phosphoinositide hydrolysis-linked serotonergic (5-HT-2 and 5-HT-1c) receptors. J Pharmacol Exp Ther 242:552-557.

Cornea-Hebert V, Riad M, Wu C, Singh SK, Descarries L (1999) Cellular and subcellular distribution of the serotonin 5-HT2A receptor in the central nervous system of adult rat. J Comp Neurol 409:187-209.

Dori I, Dinopoulos A, Blue ME, Parnavelas JG (1996) Regional differences in the ontogeny of the serotonergic projection to the cerebral cortex. Exp Neurol 138:1-14.

Eriksson KS, Stevens DR, Haas HL (2001) Serotonin excites tuberomammillary neurons by activation of $\mathrm{Na}(+) / \mathrm{Ca}(2+)$-exchange. Neuropharmacology 40:345-351.

Foehring RC, van Brederode JF, Kinney GA, Spain WJ (2002) Serotonergic modulation of supragranular neurons in rat sensorimotor cortex. J Neurosci 22:8238-8250.

Fuster JM (1985) The prefrontal cortex, mediator of cross-temporal contingencies. Hum Neurobiol 4:169-179.

Fuster JM (1991) The prefrontal cortex and its relation to behavior. Prog Brain Res 87:201-211.

Goldman-Rakic PS (1987) Circuitry of the frontal association cortex and its relevance to dementia. Arch Gerontol Geriatr 6:299-309.

Goldman-Rakic PS (1994) Working memory dysfunction in schizophrenia. J Neuropsychiatry Clin Neurosci 6:348-357.

Goldman-Rakic PS (1995) Architecture of the prefrontal cortex and the central executive. Ann NY Acad Sci 769:71-83.

Groenewegen HJ (1988) Organization of the afferent connections of the mediodorsal thalamic nucleus in the rat, related to the mediodorsalprefrontal topography. Neuroscience 24:379-431.

Gross C, Zhuang X, Stark K, Ramboz S, Oosting R, Kirby L, Santarelli L, Beck S, Hen R (2002) Serotonin1A receptor acts during development to establish normal anxiety-like behaviour in the adult. Nature 416:396-400.

Hwang LL, Dun NJ (1998) 5-Hydroxytryptamine responses in immature rat rostral ventrolateral medulla neurons in vitro. J Neurophysiol 80:1033-1041.

Hwang LL, Dun NJ (1999) 5-HT modulates multiple conductances in immature rat rostral ventrolateral medulla neurones in vitro. J Physiol (Lond) 517:217-228.
Ike J, Canton H, Sanders-Bush E (1995) Developmental switch in the hippocampal serotonin receptor linked to phosphoinositide hydrolysis. Brain Res 678:49-54.

Jones EG (1997) Cortical development and thalamic pathology in schizophrenia. Schizophr Bull 23:483-501.

Jones EG, Coulter JD, Burton H, Porter R (1977) Cells of origin and terminal distribution of corticostriatal fibers arising in the sensory-motor cortex of monkeys. J Comp Neurol 173:53-80.

Kolb B (1984) Functions of the frontal cortex of the rat: a comparative review. Brain Res 320:65-98.

Krettek JE, Price JL (1977) The cortical projections of the mediodorsal nucleus and adjacent thalamic nuclei in the rat. J Comp Neurol 171:157-191.

Lambe EK, Goldman-Rakic PS, Aghajanian GK (2000) Serotonin induces EPSCs preferentially in layer $\mathrm{V}$ pyramidal neurons of the frontal cortex in the rat. Cereb Cortex 10:974-980.

Larkman PM, Kelly JS (1997) Modulation of IH by 5-HT in neonatal rat motoneurones in vitro: mediation through a phosphorylation independent action of cAMP. Neuropharmacology 36:721-733.

Larkman PM, Kelly JS (1998) Characterization of 5-HT-sensitive potassium conductances in neonatal rat facial motoneurones in vitro. J Physiol (Lond) 508:67-81.

Lauder JM (1990) Ontogeny of the serotonergic system in the rat: serotonin as a developmental signal. Ann NY Acad Sci 600:297-313.

Lauder JM, Bloom FE (1974) Ontogeny of monoamine neurons in the locus coeruleus, Raphe nuclei and substantia nigra of the rat. I. Cell differentiation. J Comp Neurol 155:469-481.

Laurent A, Goaillard JM, Cases O, Lebrand C, Gaspar P, Ropert N (2002) Activity-dependent presynaptic effect of serotonin $1 \mathrm{~B}$ receptors on the somatosensory thalamocortical transmission in neonatal mice. J Neurosci 22:886-900.

Le Gros Clark WE (1932) The structure and connections of the thalamus. Brain 55:406-470.

Levesque M, Parent A (1998) Axonal arborization of corticostriatal and corticothalamic fibers arising from prelimbic cortex in the rat. Cereb Cortex $8: 602-613$.

Lewis DA, Levitt P (2002) Schizophrenia as a disorder of neurodevelopment. Annu Rev Neurosci 25:409-432.

Lidov HG, Molliver ME (1982) An immunohistochemical study of serotonin neuron development in the rat: ascending pathways and terminal fields. Brain Res Bull 8:389-430.

Marek GJ, Aghajanian GK (1998) The electrophysiology of prefrontal serotonin systems: therapeutic implications for mood and psychosis. Biol Psychiatry 44:1118-1127.

McCormick DA, Pape HC (1990a) Noradrenergic and serotonergic modulation of a hyperpolarization-activated cation current in thalamic relay neurones. J Physiol (Lond) 431:319-342.

McCormick DA, Pape HC (1990b) Properties of a hyperpolarizationactivated cation current and its role in rhythmic oscillation in thalamic relay neurones. J Physiol (Lond) 431:291-318.

McCormick DA, Prince DA (1987) Post-natal development of electrophysiological properties of rat cerebral cortical pyramidal neurones. J Physiol (Lond) 393:743-762.

McCormick DA, Wang Z (1991) Serotonin and noradrenaline excite GABAergic neurones of the guinea-pig and cat nucleus reticularis thalami. J Physiol (Lond) 442:235-255.

Micheva KD, Beaulieu C (1996) Quantitative aspects of synaptogenesis in the rat barrel field cortex with special reference to GABA circuitry. J Comp Neurol 373:340-354.

O'Leary DD, Ruff NL, Dyck RH (1994) Development, critical period plasticity, and adult reorganizations of mammalian somatosensory systems. Curr Opin Neurobiol 4:535-544.

Ongur D, Price JL (2000) The organization of networks within the orbital and medial prefrontal cortex of rats, monkeys and humans. Cereb Cortex 10:206-219.

Paxinos G, Watson C (1998) The rat brain in stereotaxic coordinates, Ed 4. New York: Academic.

Raedler TJ, Knable MB, Weinberger DR (1998) Schizophrenia as a developmental disorder of the cerebral cortex. Curr Opin Neurobiol 8:157-161.

Rakic P, Goldman-Rakic PS (1982) The development and modifiability of the cerebral cortex. Overview. Neurosci Res Program Bull 20:433-438.

Reyes A, Sakmann B (1999) Developmental switch in the short-term mod- 
ification of unitary EPSPs evoked in layer 2/3 and layer 5 pyramidal neurons of rat neocortex. J Neurosci 19:3827-3835.

Rhoades RW, Bennett-Clarke CA, Shi MY, Mooney RD (1994) Effects of 5-HT on thalamocortical synaptic transmission in the developing rat. J Neurophysiol 72:2438-2450.

Rice FL, Gomez C, Barstow C, Burnet A, Sands P (1985) A comparative analysis of the development of the primary somatosensory cortex: interspecies similarities during barrel and laminar development. J Comp Neurol 236:477-495.

Roerig B, Nelson DA, Katz LC (1997) Fast synaptic signaling by nicotinic acetylcholine and serotonin 5-HT3 receptors in developing visual cortex. J Neurosci 17:8353-8362.

Roth BL, Hamblin MW, Ciaranello RD (1991) Developmental regulation of 5-HT2 and 5-HT1c mRNA and receptor levels. Brain Res Dev Brain Res 58:51-58.

Salichon N, Gaspar P, Upton AL, Picaud S, Hanoun N, Hamon M, De Maeyer E, Murphy DL, Mossner R, Lesch KP, Hen R, Seif I (2001) Excessive activation of serotonin (5-HT) 1B receptors disrupts the formation of sensory maps in monoamine oxidase A and 5-HT transporter knock-out mice. J Neurosci 21:884-896.

Selemon LD, Goldman-Rakic PS (1985) Longitudinal topography and interdigitation of corticostriatal projections in the rhesus monkey. J Neurosci 5:776-794.

Sesack SR, Deutch AY, Roth RH, Bunney BS (1989) Topographical organization of the efferent projections of the medial prefrontal cortex in the rat: an anterograde tract-tracing study with Phaseolus vulgaris leucoagglutinin. J Comp Neurol 290:213-242.

Stern EA, Maravall M, Svoboda K (2001) Rapid development and plasticity of layer 2/3 maps in rat barrel cortex in vivo. Neuron 31:305-315.

Sugita S, Shen KZ, North RA (1992) 5-hydroxytryptamine is a fast excitatory transmitter at 5-HT3 receptors in rat amygdala. Neuron 8:199-203.
Talley EM, Sadr NN, Bayliss DA (1997) Postnatal development of serotonergic innervation, 5-HT1A receptor expression, and 5-HT responses in rat motoneurons. J Neurosci 17:4473-4485.

Tanaka E, North RA (1993) Actions of 5-hydroxytryptamine on neurons of the rat cingulate cortex. J Neurophysiol 69:1749-1757.

Uylings HB, van Eden CG (1990) Qualitative and quantitative comparison of the prefrontal cortex in rat and in primates, including humans. Prog Brain Res 85:31-62.

Van Eden CG, Uylings HB (1985) Cytoarchitectonic development of the prefrontal cortex in the rat. J Comp Neurol 241:253-267.

Wang MY, Dun NJ (1990) 5-Hydroxytryptamine responses in neonate rat motoneurones in vitro. J Physiol (Lond) 430:87-103.

Weinberger DR, Berman KF (1996) Prefrontal function in schizophrenia: confounds and controversies. Philos Trans R Soc Lond B Biol Sci 351:1495-1503.

Yakel JL, Jackson MB (1988) 5-HT3 receptors mediate rapid responses in cultured hippocampus and a clonal cell line. Neuron 1:615-621.

Yan W, Wilson CC, Haring JH (1997) Effects of neonatal serotonin depletion on the development of rat dentate granule cells. Brain Res Dev Brain Res 98:177-184.

Yang J, Mathie A, Hille B (1992) 5-HT3 receptor channels in dissociated rat superior cervical ganglion neurons. J Physiol (Lond) 448:237-256.

Zhang ZW, Deschenes M (1997) Intracortical axonal projections of lamina VI cells of the primary somatosensory cortex in the rat: a single-cell labeling study. J Neurosci 17:6365-6379.

Zhou FM, Hablitz JJ (1999) Activation of serotonin receptors modulates synaptic transmission in rat cerebral cortex. J Neurophysiol 82:2989-2999.

Zilles K, Schleicher A, Glaser T, Traber J, Rath M (1985) The ontogenetic development of serotonin (5-HT1) receptors in various cortical regions of the rat brain. Anat Embryol (Berl) 172:255-264 